\title{
Microbial community structure in the western tropical South Pacific
}

\author{
Nicholas Bock ${ }^{1}$, France Van Wambeke ${ }^{2}$, Moïra Dion ${ }^{3}$, and Solange Duhamel ${ }^{1}$ \\ ${ }^{1}$ Lamont-Doherty Earth Observatory, Division of Biology and Paleo Environment, Columbia University, \\ P.O. Box 1000, 61 Route 9W, Palisades, New York 10964, USA \\ ${ }^{2}$ Aix-Marseille Université, CNRS, Université de Toulon, IRD, OSU Pythéas, Mediterranean Institute of \\ Oceanography (MIO), UM110, 13288, Marseille, France \\ ${ }^{3}$ Département de biochimie, de microbiologie et de bio-informatique, Faculté des sciences et de génie, \\ Université Laval, 2325, rue de l’Université, Québec (QC), G1V 0A6, Canada
}

Correspondence: Nicholas Bock (nab2161@1deo.columbia.edu)

Received: 29 December 2017 - Discussion started: 7 February 2018

Revised: 10 May 2018 - Accepted: 8 June 2018 - Published: 29 June 2018

\begin{abstract}
Oligotrophic regions play a central role in global biogeochemical cycles, with microbial communities in these areas representing an important term in global carbon budgets. While the general structure of microbial communities has been well documented in the global ocean, some remote regions such as the western tropical South Pacific (WTSP) remain fundamentally unexplored. Moreover, the biotic and abiotic factors constraining microbial abundances and distribution remain not well resolved. In this study, we quantified the spatial (vertical and horizontal) distribution of major microbial plankton groups along a transect through the WTSP during the austral summer of 2015, capturing important autotrophic and heterotrophic assemblages including cytometrically determined abundances of non-pigmented protists (also called flagellates). Using environmental parameters (e.g., nutrients and light availability) as well as statistical analyses, we estimated the role of bottom-up and top-down controls in constraining the structure of the WTSP microbial communities in biogeochemically distinct regions. At the most general level, we found a "typical tropical structure", characterized by a shallow mixed layer, a clear deep chlorophyll maximum at all sampling sites, and a deep nitracline. Prochlorococcus was especially abundant along the transect, accounting for $68 \pm 10.6 \%$ of depth-integrated phytoplankton biomass. Despite their relatively low abundances, picophytoeukaryotes (PPE) accounted for up to $26 \pm 11.6 \%$ of depth-integrated phytoplankton biomass, while Synechococcus accounted for only $6 \pm 6.9 \%$. Our results show that the
\end{abstract}

microbial community structure of the WTSP is typical of highly stratified regions, and underline the significant contribution to total biomass by PPE populations. Strong relationships between $\mathrm{N}_{2}$ fixation rates and plankton abundances demonstrate the central role of $\mathrm{N}_{2}$ fixation in regulating ecosystem processes in the WTSP, while comparative analyses of abundance data suggest microbial community structure to be increasingly regulated by bottom-up processes under nutrient limitation, possibly in response to shifts in abundances of high nucleic acid bacteria (HNA).

\section{Introduction}

Subtropical oligotrophic gyres, accounting for $45 \%$ of global ocean area, represent one of the earth's largest biomes (Sarmiento et al., 2004). Despite reduced productivity compared to coastal regions, these nutrient-limited ecosystems are estimated to account for nearly one-quarter of annual net marine primary production (Field, 1998). Therefore, it is of central importance to understand the factors shaping microbial communities in these regions, and to account for how these factors might vary seasonally and geographically between the ocean's major oligotrophic regions. There has been a great deal of progress toward this goal over the last three decades. The groups of phytoplankton that numerically dominate the open ocean - Prochlorococcus, Synechococcus, and picophytoeukaryotes (PPE) - are of a small size, gener- 
ally $<2 \mu \mathrm{m}$, with the most abundant group, Prochlorococcus, identified in the late 1980s (Chisholm et al., 1988). Since then, the widespread use of flow cytometry to characterize microbial communities has led to the publication of numerous studies documenting the distribution of these organisms (Veldhuis and Kraay, 2000). Especially over the last 10 years, molecular methodologies have allowed for the characterization of these groups at the taxon or species level, revealing enormous diversity across all trophic levels of marine microbial communities and identifying numerous ecotypes occupying distinct ecological niches (Carlson et al., 2007; Venter et al., 2004). More recently, environmental sequencing has revealed a surprising diversity of small-sized PPE and new eukaryotic lineages continue to be discovered and characterized (Kashtan et al., 2014; Kim et al., 2016; Lepère et al., 2009; Rii et al., 2016a), while also revealing the importance of viruses in regulating phytoplankton communities (Brum et al., 2015; Huang et al., 2015).

However, the role of physical and biogeochemical processes in shaping microbial communities in the oligotrophic ocean remains unclear. While some general in situ trends are apparent - for example the predominance of Synechococcus and PPE in nutrient-rich waters and the predominance of Prochlorococcus in nutrient-depleted regions - spatial and temporal variability provides significant challenges to the generalization of these patterns at a global level (Fuhrman, 2009). And while there are accounts of microbial community structure in oligotrophic regions of the North Atlantic (Partensky et al., 1996) and North Pacific (Campbell and Vaulot, 1993; Karl, 1999), as well as for the Mediterranean (Denis et al., 2010) and Arabian (Campbell et al., 1998) seas, the South Pacific remains less well documented. Although there are three reports on the distribution of bacteria, Prochlorococcus, Synechococcus and PPE abundance and biomass in the oligotrophic subtropical southeastern Pacific (Grob et al., 2007a, b; Lepère et al., 2009), and two papers describing cell abundance distribution of Prochlorococcus, Synechococcus and PPE in the southwestern Pacific near New Caledonia (Blanchot and Rodier, 1996; Tenório et al., 2018), there are no reports on community structure in the oligotrophic regions of the western tropical South Pacific (WTSP). Moreover, despite their crucial role as grazers of microbial plankton, small-sized heterotrophic protists (i.e., non-pigmented cells between $\sim 2$ and $5 \mu \mathrm{m}$, hereafter HNF), also called flagellates, have received little attention (Christaki et al., 2011). Although there have been an increasing number of reports focusing on their role as predators over the last couple of decades, HNF are not routinely measured and their distribution relative to other microbial groups is not well constrained (Christaki et al., 2011).

In this study, we present an account of microbial plankton community structure during late austral summer in distinct biogeochemical regions of the WTSP, ranging from mesotrophy to ultraoligotrophy. Our primary goal is to document the microbial community structure in the region, based on flow cytometry data capturing bacterioplankton (low-DNA content, LNA, and high-DNA content, HNA), phytoplankton (Prochlorococcus, Synechococcus and PPE) and HNF groups. In addition, we describe the dominant biogeochemical gradients observed along the cruise transect, and attempt to identify the physical and ecological variables influencing the abundance and distribution of plankton groups in the region. We also compare several previously published empirical models that make use of bacteria and HNF abundances to evaluate trophic interactions between populations of heterotrophic plankton groups.

\section{Material and methods}

\subsection{Field sampling}

A zonal characterization of the biogeochemistry and biological diversity of the western tropical South Pacific (WTSP) was conducted along trophic gradients during the OUTPACE cruise (Oligotrophy to UlTra-oligotrophy PACific Experiment, https://doi.org/10.17600/15000900, RV L'Atalante, February-April 2015) between New Caledonia and Tahiti (Moutin et al., 2017). To describe the longitudinal and vertical distribution of different groups of pico- and nanoplankton, we sampled 15 short-duration stations (SD1 to SD15, occupied during $8 \mathrm{~h}$, Fig. 1). Three long-duration stations (LDA, LDB, and LDC, occupied during 7 days), chosen for their contrasted biogeochemical conditions (Table 1), were sampled in Lagrangian mode (de Verneil et al., 2017). In keeping with Moutin et al. (2017), stations sampling the waters of the Melanesian Archipelago (SD1 to SD12 and LDA) were classified as MA, while stations sampling the western South Pacific Gyre (SD13 to SD15 and LDC) were classified as GY. Long-duration station B was in the late stages of a phytoplankton bloom at the time of sampling (de Verneil et al., 2018). As such, the station was analyzed independently of other stations on the transect, and is simply referred to as LDB. All stations were sampled at 12 different depths from the surface down to $200 \mathrm{~m}$ for microbial characterization of the extended photic layer. The photic layer $\mathrm{Z}_{\mathrm{e}}(\mathrm{m})$ is defined as the sunlit layer of the water column between the surface and the depth where irradiance is reduced to $0.1 \%$ of its surface value.

\subsection{Pico- and nano-plankton analyses}

For cell enumeration, duplicate $1.8 \mathrm{~mL}$ samples were fixed $(0.25 \%$ electron microscopy grade paraformaldehyde, $w / v)$ for $10-15 \mathrm{~min}$ at room temperature and in the dark, flashfrozen in liquid nitrogen and stored at $-80^{\circ} \mathrm{C}$ for later analysis using a BD Influx flow cytometer (BD Biosciences, San Jose, CA, USA). Pigmented groups, Prochlorococcus, Synechococcus and PPE, were enumerated in unstained samples for $5 \mathrm{~min}$ at $\sim 61 \mu \mathrm{L} \mathrm{min}{ }^{-1}$. Bacteria were discriminated in a sample aliquot stained with SYBR Green I DNA dye 
Table 1. Summary of average depth-integrated abundances for Prochlorococcus (Pro), Synechococcus (Syn), picophytoeukaryotes (PPE), and bacteria $(\mathrm{Bac})$, in addition to depth-normalized values of nutrient concentrations $\left(\mathrm{NO}_{x}\right.$ and $\left.\mathrm{PO}_{4}\right)$, for different vertical zones $\left(\mathrm{Z}_{\mathrm{u}}, \mathrm{Z}_{1}\right.$ and $\mathrm{Z}_{\mathrm{e}}$ ) and for individual biogeochemical conditions (cond.: MA, LDB, and GY). ${ }^{*} \mathrm{NO}_{2}+\mathrm{NO}_{3}$.

\begin{tabular}{ccccccccc}
\hline cond. & zone & $\begin{array}{c}\text { Pro } \\
10^{11} \text { cells m}^{-2}\end{array}$ & $\begin{array}{c}\text { Syn } \\
10^{11} \text { cells m}^{-2}\end{array}$ & $\begin{array}{c}\text { PPE } \\
10^{11} \text { cells m}^{-2}\end{array}$ & $\begin{array}{c}\text { Bac } \\
10^{11} \text { cells m}^{-2}\end{array}$ & $\begin{array}{c}\mathrm{HNF} \\
10^{11} \text { cells m}^{-2}\end{array}$ & $\begin{array}{c}\mathrm{NO}_{x}{ }^{*} \\
\mathrm{mmol} \mathrm{m}^{-3}\end{array}$ & $\begin{array}{c}\mathrm{PO}_{4} \\
\mathrm{mmol} \mathrm{m}^{-3}\end{array}$ \\
\hline MA & $\mathrm{Z}_{\mathrm{u}}$ & $122 \pm 31$ & $3.42 \pm 2.44$ & $0.50 \pm 0.10$ & $271 \pm 73$ & $0.57 \pm 0.10$ & $0.02 \pm 0.01$ & $0.05 \pm 0.04$ \\
& $\mathrm{Z}_{\mathrm{l}}$ & $71 \pm 24$ & $0.79 \pm 0.42$ & $1.18 \pm 0.33$ & $139 \pm 26$ & $0.40 \pm 0.09$ & $0.43 \pm 0.42$ & $0.12 \pm 0.05$ \\
& $\mathrm{Z}_{\mathrm{e}}$ & $194 \pm 52$ & $4.21 \pm 2.53$ & $1.68 \pm 0.36$ & $410 \pm 97$ & $0.97 \pm 0.18$ & $0.22 \pm 0.21$ & $0.08 \pm 0.03$ \\
\hline LDB & $\mathrm{Z}_{\mathrm{u}}$ & $183 \pm 28$ & $16.14 \pm 8.64$ & $0.42 \pm 0.07$ & $424 \pm 108$ & $0.91 \pm 0.35$ & $0.01 \pm 0.01$ & $0.03 \pm 0.01$ \\
& $\mathrm{Z}_{\mathrm{l}}$ & $65 \pm 30$ & $2.31 \pm 1.13$ & $0.81 \pm 0.55$ & $131 \pm 40$ & $0.36 \pm 0.07$ & $0.02 \pm 0.01$ & $0.07 \pm 0.02$ \\
& $\mathrm{Z}_{\mathrm{e}}$ & $248 \pm 56$ & $18.45 \pm 7.68$ & $1.24 \pm 0.52$ & $555 \pm 141$ & $1.27 \pm 0.28$ & $0.02 \pm 0.02$ & $0.05 \pm 0.01$ \\
\hline $\mathrm{GY}$ & $\mathrm{Z}_{\mathrm{u}}$ & $110 \pm 9$ & $0.54 \pm 0.20$ & $0.63 \pm 0.09$ & $290 \pm 32$ & $0.41 \pm 0.06$ & $0.02 \pm 0.01$ & $0.13 \pm 0.03$ \\
& $\mathrm{Z}_{\mathrm{l}}$ & $89 \pm 10$ & $0.35 \pm 0.06$ & $1.26 \pm 0.24$ & $164 \pm 17$ & $0.43 \pm 0.03$ & $0.77 \pm 0.42$ & $0.20 \pm 0.05$ \\
& $\mathrm{Z}_{\mathrm{e}}$ & $199 \pm 9$ & $0.89 \pm 0.20$ & $1.89 \pm 0.31$ & $455 \pm 30$ & $0.85 \pm 0.05$ & $0.39 \pm 0.20$ & $0.17 \pm 0.03$ \\
\hline
\end{tabular}

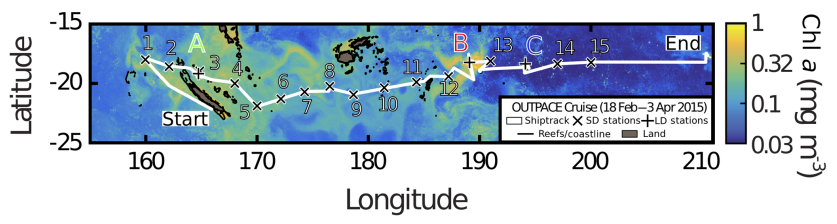

Figure 1. Quasi-Lagrangian surface chlorophyll- $a$ concentration $\left(\mathrm{mg} \mathrm{m}^{-3}\right)$ in the sampling region. Data represent the mean chlorophyll- $a$ concentration in March 2015. The white line identifies the track of the OUTPACE cruise, with the sampled stations marked 1 to $15(\mathrm{x})$ and the long-duration stations marked A, B and $\mathrm{C}(+)$.

(1: 10000 final) and enumerated for $1 \mathrm{~min}$ at $\sim 65 \mu \mathrm{L} \mathrm{min}^{-1}$. HNF were analyzed for $8 \mathrm{~min}$ at $\sim 193 \mu \mathrm{L} \mathrm{min}^{-1}$ in a sample stained with SYBR Green I at 1:5000 final concentration (Christaki et al., 2011; Zubkov et al., 2007). Particles were excited at $488 \mathrm{~nm}$ (plus $457 \mathrm{~nm}$ for unstained samples). Forward $\left(<15^{\circ}\right)$ scatter $(\mathrm{FSC})$, side $\left(90^{\circ}\right)$ scatter (SSC), green fluorescence $(530 / 40 \mathrm{~nm})$, orange fluorescence $(580 / 30 \mathrm{~nm})$ and red fluorescence $(>650 \mathrm{~nm}$ ) emissions were measured. Pigmented groups were identified and enumerated based on their chlorophyll (red) fluorescence and FSC (size) signatures. The high phycoerythrin (orange) signal in Synechococcus was used to distinguish them from Prochlorococcus and PPE. Using a FSC detector with a small particle option and focusing a 488 plus a $457 \mathrm{~nm}$ ( 200 and $300 \mathrm{~mW}$ solid state, respectively) laser into the same pinhole greatly improved the resolution of dim surface Prochlorococcus population from background noise (Duhamel et al., 2014). LNA and HNA bacteria were discriminated based on their low and high green fluorescence, respectively, in an SSC vs. green fluorescence plot (Vazquez-Dominguez et al., 1999; Van Wambeke et al., 2011). In samples from the upper euphotic layer, where the Prochlorococcus signal at times overlapped with that of HNA in SSC or FSC vs. green fluorescence plots, Prochloro- coccus abundance counted in unstained samples was subtracted from the HNA abundance enumerated in a larger gate. "Total bacteria" refers to the sum of LNA and HNA abundances. Reference beads (Fluoresbrite, YG, $1 \mu \mathrm{m}$ ) were added to each sample and red fluorescence from chlorophyll and FSC values are presented relative to the reference beads (arbitrary units, A.U.).

$\mathrm{N}_{2}$ fixation rates were measured in triplicate at all stations (except SD13) using the ${ }^{15} \mathrm{~N}_{2}$ isotopic tracer technique (adapted from Montoya et al. 1996). Briefly, seawater samples were collected in $\mathrm{HCl}$-washed, sample-rinsed $(3 \times)$ light-transparent polycarbonate $2.3 \mathrm{~L}$ bottles from six depths $(75,50,20,10,1$, and $0.1 \%$ surface irradiance levels), sealed with caps fitted with silicon septa and amended with $2 \mathrm{~mL}$ of 98.9 at. $\%{ }^{15} \mathrm{~N}_{2}$ (Cambridge isotopes). Incubation bottles were incubated in on-deck incubators equipped with circulating seawater at the specified irradiances using blue screening. Incubations were stopped by filtration of the entire sample onto precombusted $25 \mathrm{~mm}$ GF/F glass fiber (Whatman, $0.7 \mu \mathrm{m}$ nominal pore size) filters, which were then analyzed for ${ }^{15} \mathrm{~N} /{ }^{14} \mathrm{~N}$ ratios and PON concentrations using an elemental analyzer coupled to a mass spectrometer (EA-IRMS, Integra CN, SerCon Ltd) as described in Bonnet et al. (2018).

\subsection{Data analyses and statistics}

All data analyses were performed using R Studio (R Core Team, 2016). All figures were prepared using the ggplot2 package (Wickham, 2009), with the exception of the contour plots presented in Fig. 2, which were prepared using Ocean Data View 4.7.10 (Schlitzer, 2017).

Chlorophyll fluorescence of microbial groups was calculated as the ratio of mean red fluorescence of each cell population to that of the reference beads, based on flow cytometry results. Per-cell biomass was calculated using previously published conversion factors: $29 \mathrm{fg} \mathrm{C}$ per Prochlorococcus cell, $100 \mathrm{fg}$ C per Synechococcus cell, $11.5 \mathrm{fg}$ C per bacte- 

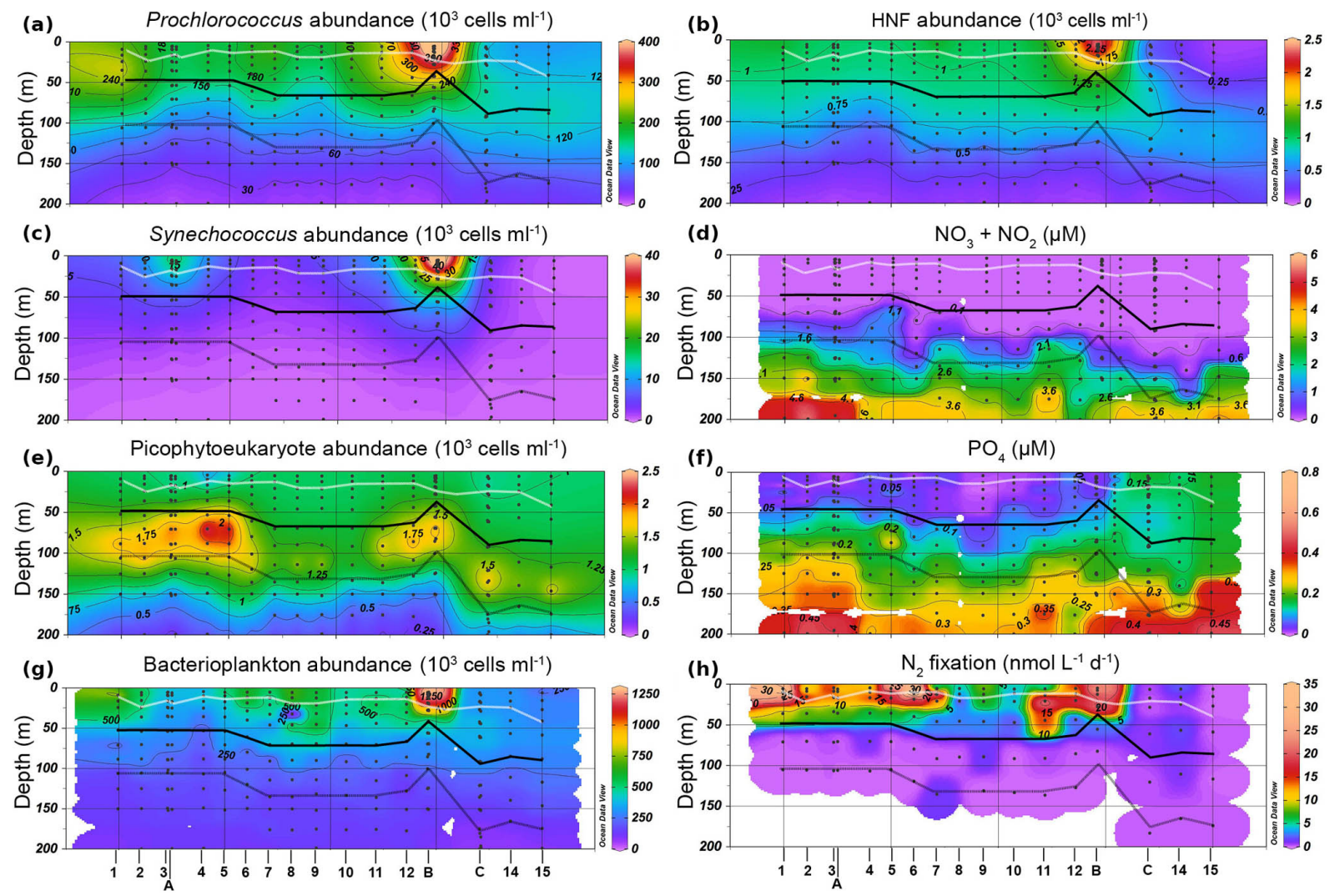

Figure 2. Contour plots depicting plankton abundances (a, b, c, d, e), nutrient concentrations (f, $\mathbf{g}$ ) and $\mathrm{N}_{2}$ fixation (h) distributions along the OUTPACE transect. White line represents the mixed layer depth. The black solid line represents the PAR 2.7 depth. Grey line represents $\operatorname{PAR}_{0.1}$.

rial cell, and $1500 \mathrm{fg} \mathrm{C}$ per PPE cell (Zubkov et al., 2000). Biomass contributions of different phytoplankton groups were estimated by multiplying cell abundances by the conversion factors above and integrating by depth across the euphotic zone. To account for larger eukaryotes not captured by cytometry, we used the method described in Vidussi et al. (2001) to estimate the relative biomass contributions of diatoms and dinoflagellates based on concentrations of fucoxanthin and peridinin relative to those of total diagnostic pigments: zeaxanthin, $\mathrm{dv} \operatorname{chl} a, T \operatorname{chl} b, 19^{\prime}$ hexanoyloxyfucoxanthin $\left(19^{\prime}\right.$-HF), 19' butanoyloxyfucoxanthin $\left(19^{\prime}\right.$ $\mathrm{BF})$, alloxanthin, fucoxanthin, and peridinin. Pigment concentrations were measured via high-performance liquid chromatography, as described elsewhere (Ras et al., 2008).

Concentrations of $\mathrm{PO}_{4}, \mathrm{NO}_{2}$, and $\mathrm{NO}_{3}$ were measured using a SEAL AA3 HR auto-analyzer (SEAL Analytical, UK), as described by Moutin et al. (2018). Abundances, biomass, and nutrient values are reported as either depth-integrated totals or as depth-normalized averages calculated by dividing depth-integrated totals by the depth of integration. In order to account for large vertical gradients in both abundances and nutrient concentrations within the $Z_{\mathrm{e}}$, integrations were performed across two depth ranges: the upper photic zone
$\left(\mathrm{Z}_{\mathrm{u}}\right)$, integrating from the surface to the recorded $2.7 \%$ isolume (hereafter $\left.\mathrm{PAR}_{2.7}\right)$ and the lower euphotic zone $\left(\mathrm{Z}_{1}\right)$, integrating from $\mathrm{PAR}_{2.7}$ to the recorded $0.1 \%$ isolume (hereafter $\left.\mathrm{PAR}_{0.1}\right)$. The mixed layer depth was measured continuously along the transect, as described by de Verneil et al. (2017). The mixed layer was entirely within $Z_{u}$ at all stations (Fig. 2), while the nitracline, defined as the depth where measurements of $\mathrm{NO}_{2}+\mathrm{NO}_{3}$ (hereafter $\mathrm{NO}_{x}$ ) first exceed $0.1 \mu \mathrm{M}$, occurred within $Z_{1}$ at all stations (Fig. 2f). Attenuation coefficients, $k\left(\mathrm{~m}^{-1}\right)$, were calculated by using PAR measurements from conductivity, temperature, depth (CTD) sensors to solve the Beer-Lambert equation between surface PAR and that corresponding to $\mathrm{PAR}_{0.1}$.

To maximize the power of statistical tests, depth-integrated values were calculated for individual casts, without averaging results from long-duration stations. Because each cast was made on a different day of occupation, doing so did not violate assumptions of independence during subsequent statistical analyses. Integration results were then assigned categorical variables corresponding to biogeochemical condition or euphotic zone layer, with two-way ANOVA being used to identify statistical relationships between parameters according to these variables (Table 2). Tukey's honest significant 
Table 2. Summary table of two-way ANOVA results for parameters analyzed in this study. Row 1 (euphotic layer) tests for significant differences between mean parameter values across different layers of the euphotic layer $\left(Z_{\mathrm{u}}\right.$ or $\left.\mathrm{Z}_{1}\right)$ on mean parameter values. Row 2 (area) tests for significant differences between mean parameter values across different biogeochemical areas (MA, LDB, and GY). Row 3 (interaction) tests for differences between mean parameter values across both euphotic layer and biogeochemical condition. Relationships for Pro, Bac, $\mathrm{HNF}, \mathrm{NO}_{x}$, and $\mathrm{PO}_{4}$ calculated from depth-integrated abundances; relationships for \%HNA calculated from raw values.

\begin{tabular}{|c|c|c|c|c|c|c|c|c|c|c|c|c|c|c|c|c|c|}
\hline & \multirow[b]{2}{*}{ DF } & \multicolumn{2}{|c|}{ Pro } & \multicolumn{2}{|c|}{ Syn } & \multicolumn{2}{|c|}{ PPE } & \multicolumn{2}{|c|}{$\mathrm{Bac}$} & \multicolumn{2}{|c|}{$\%$ HNA } & \multicolumn{2}{|c|}{$\mathrm{HNF}$} & \multicolumn{2}{|c|}{$\mathrm{NO}_{x}$} & \multicolumn{2}{|c|}{$\mathrm{PO}_{4}$} \\
\hline & & $f$ & $p$ & $f$ & $p$ & $f$ & $p$ & $f$ & $p$ & $f$ & $p$ & $f$ & $p$ & $f$ & $p$ & $f$ & $p$ \\
\hline Layer & 1 & 49.2 & $<0.01$ & 23.3 & $<0.01$ & 68.1 & $<0.01$ & 88.3 & $<0.01$ & 5.4 & 0.02 & 24.7 & $<0.01$ & 42.4 & $<0.01$ & 40.6 & $<0.01$ \\
\hline Area & 2 & 2.9 & 0.1 & 25.9 & $<0.01$ & 3.2 & 0.1 & 4.6 & 0.2 & 16.9 & $<0.01$ & 6.0 & 0.01 & 12.6 & $<0.01$ & 113.2 & $<0.01$ \\
\hline Int. & 2 & 7.0 & $<0.01$ & 15.8 & $<0.01$ & 0.9 & 0.4 & 6.0 & 0.01 & 0.7 & 0.50 & 11.3 & $<0.01$ & 11.9 & $<0.01$ & 3.01 & 0.1 \\
\hline
\end{tabular}

difference post hoc test was used to compare group means when two-way ANOVA indicated significant between-group differences. To ensure that data met the requirements for ANOVA (i.e., normally distributed, and with equal variance between groups), values were log-transformed before performing statistical tests. In the case of nutrient data and $\mathrm{N}_{2}$ fixation rates, which were often skewed by large occurrences of small values, data were transformed using the formula data $=\log ($ data $\times 100+1)$. Bivariate comparisons between biogeochemical parameters were performed using Pearson's correlation. The Shapiro-Wilk test was used to assess normality, while Levene's test was used to confirm homogeneity of variance.

\section{Results}

\subsection{Physico-chemical characteristics of the studied area}

Stations along the transect were characterized by warm sea surface temperatures (mean $29.4 \pm 0.4{ }^{\circ} \mathrm{C}$ ). The water column was strongly stratified along the entire transect, with mixed layer depths ranging from $21 \pm 5 \mathrm{~m}$ for MA to $25 \pm 8 \mathrm{~m}$ for GY (Fig. 2). Conversely, there was a significant west to east decrease in light attenuation $(k)$, ranging from $0.059 \pm 0.006 \mathrm{~m}^{-1}$ for MA to $0.044 \pm 0.005 \mathrm{~m}^{-1}$ for GY. An exception to this trend was found at LDB, where $k$ increased to $0.078 \pm 0.021$. Corresponding to these changes in $k, \mathrm{PAR}_{0.1}$ deepened from west to east, ranging from $113 \pm 13 \mathrm{~m}$ for MA to $178 \pm 5 \mathrm{~m}$ for GY. Again, LDB presented an exception to this general trend, where $\mathrm{PAR}_{0.1}$ was recorded at $83 \pm 5 \mathrm{~m}$.

All stations across the transect featured a prominent deep chlorophyll maximum (DCM). Mirroring changes in $k$, the DCM showed a general increase in depth from west to east, ranging from $85 \pm 20$ to $133 \pm 20 \mathrm{~m}$ from MA to GY, respectively. The DCM depth at LDB was also an exception, decreasing to $50 \pm 19 \mathrm{~m}$. The concentration of dissolved oxygen was near equilibrium with the atmosphere near the surface, becoming slightly oversaturated below the mixed layer. This subsurface maximum occurred at a mean depth of $55 \pm 18 \mathrm{~m}$ and was weakly correlated with the depth of the DCM (Pearson's $r=0.44, p<0.01$ ). Oxygen levels within
$\mathrm{Z}_{\mathrm{e}}$ were above $158.31 \mathrm{~mol} \mathrm{~kg}^{-1}$ across the entire transect, with there being no suboxic regions at any of the stations sampled. The nitracline generally tracked the DCM, occurring at depths ranging from $93 \pm 17 \mathrm{~m}$ for MA to $127 \pm 13 \mathrm{~m}$ for GY. The nitracline was decoupled from the DCM at LDB, where it occurred at $108 \pm 22 \mathrm{~m}$.

$\mathrm{NO}_{x}$ concentrations were depleted in $\mathrm{Z}_{\mathrm{u}}$ across all biogeochemical conditions. While depth-normalized $\mathrm{NO}_{x}$ concentrations were significantly elevated in $\mathrm{Z}_{1}$ for $\mathrm{MA}$ and $\mathrm{GY}$ (ANOVA, $p<0.01$ ), no significant difference was encountered between $Z_{\mathrm{u}}$ and $\mathrm{Z}_{1}$ at LDB (Table 1). Depth-normalized phosphate $\left(\mathrm{PO}_{4}\right)$ concentrations in $\mathrm{Z}_{\mathrm{u}}$ were significantly elevated at GY relative to other stations (ANOVA, $p<0.01$ ), although no significant differences were identified between MA and LDB.

\subsection{Phytoplankton community structure}

Prochlorococcus dominated phytoplankton abundances at all sampling sites, with average $\mathrm{Z}_{\mathrm{e}}$-integrated abundances being 2 orders of magnitude greater than those of Synechococcus and PPE (Table 1). $\mathrm{Z}_{\mathrm{e}}$-integrated Prochlorococcus abundances ranged from $135 \times 10^{11}$ at SD3 to $283 \times 10^{11}$ cells $\mathrm{m}^{-2}$ at SD1, while those for Synechococcus ranged from $0.65 \times 10^{11}$ at SD15 to $18.62 \times 10^{11}$ cells m$^{-2}$ at LDB. PPE abundances ranged from $1.40 \times 10^{11}$ to $2.60 \times 10^{11}$ cells $\mathrm{m}^{-2}$ at SD3 and SD12, respectively. There were no significant differences in $\mathrm{Z}_{\mathrm{e}}$-integrated abundances of these groups across biogeochemical conditions, except for those of Synechococcus, which were significantly greater at LDB compared to MA or GY (ANOVA, $p<0.01)$. Transect-wide, Prochlorococcus accounted for approximately $97 \pm 2 \%$ of total phytoplankton cells enumerated by flow cytometry. Synechococcus and PPE accounted for $2 \pm 2$ and $0.8 \pm 0.2 \%$ of total phytoplankton abundance, respectively. Pooling all data, statistically significant correlations were identified between all pairs of plankton groups (Pearson's $R, p<0.01$ ).

Based on $\mathrm{Z}_{\mathrm{e}}$-integrated abundances, relative contributions of different phytoplankton groups to total phytoplankton abundance showed considerable longitudinal variation. Synechococcus accounted for $0.4 \pm 0.1 \%$ of phytoplankton cells at GY, $2.4 \pm 1.9 \%$ at MA, and $7.4 \pm 4.4 \%$ at 
LDB. Prochlorococcus abundances, by contrast, represented $92.1 \pm 4.3 \%$ of phytoplankton cells at LDB, $96.7 \pm 2.0 \%$ at MA, and $98.6 \pm 0.2 \%$ at GY. Ratios of $\mathrm{Z}_{\mathrm{e}}$-integrated abundances of Prochlorococcus to Synechococcus varied significantly (ANOVA, $p<0.01)$ between GY $(235.7 \pm 65.1)$ and LDB (16.2 \pm 10$)$. PPE abundances showed less variability, with relative abundances ranging from $0.4 \pm 0.1$ to $0.9 \pm 0.1 \%$ of phytoplankton cells at LDB and GY, respectively. Differences in the relative abundance of PPE between biogeochemical conditions were not statistically significant. Statistically significant negative correlations were found between concentrations of $\mathrm{NO}_{x}$ and $\mathrm{PO}_{4}$ and all plankton groups (Pearson's $R, p<0.01$ ), while significant positive correlations were identified between $\mathrm{N}_{2}$ fixation rates and abundances of Prochlorococcus and heterotrophic bacteria (Pearson's $R, p<0.01$ ). These correlations persisted when subsetting data to include mixed layer values alone (Pearson's $R, p<0.01$ ), with the exception of correlations between $\mathrm{NO}_{x}$ and plankton groups.

Most stations were characterized by a well-defined twotier distribution of phytoplankton within the $Z_{\mathrm{e}}$ (Fig. 3), with depth-integrated abundances of Prochlorococcus and Synechococcus being greatest in the $\mathrm{Z}_{\mathrm{u}}$, and PPE abundances being greatest in $Z_{1}$ (Table 1). These differences between $\mathrm{Z}_{\mathrm{u}}$ and $\mathrm{Z}_{1}$ abundances were found to be statistically significant for Prochlorococcus across all conditions. Differences were significant for Synechococcus at MA, and for PPE at MA and GY (ANOVA, $p<0.01$ ). Prochlorococcus and PPE abundances showed subsurface maxima at both MA and GY. Averaging across the transect, Prochlorococcus abundance maxima occurred at depths corresponding to $24.2 \pm 24.4 \%$ PAR, while PPE maxima occurred at depths corresponding to $0.6 \pm 0.4 \%$ PAR. Depths of these maxima showed a west to east increase, and were significantly deeper at GY than at MA for all phytoplankton groups (ANOVA, $p<0.01$ ).

There was no significant variation in $Z_{\mathrm{e}}$-integrated biomass between different conditions, although $\mathrm{Z}_{\mathrm{u}^{-}}$ integrated biomass was significantly greater $(p<0.01)$ at LDB compared to MA and GY stations (Fig. 4). In keeping with relative abundances, Prochlorococcus cells represented the greatest fraction of $Z_{\mathrm{e}}$ biomass, accounting for an average of $77.1 \pm 5.5 \%$ across the transect. By comparison, PPE accounted for an average of $18.7 \pm 5.4 \%$ of $\mathrm{Z}_{\mathrm{e}}$ biomass, while Synechococcus accounted for $3.9 \pm 4.3 \%$. However, there was considerable vertical and longitudinal variation in these trends, especially in contributions to total biomass by PPE and Synechococcus populations (Fig. 4). PPE accounted for $29 \pm 14 \%$ of phytoplankton biomass considering $Z_{1}$ alone, and up to $64 \%$ of $Z_{1}$ biomass at SD4. Synechococcus accounted for up to $13 \%$ of $\mathrm{Z}_{\mathrm{u}}$ phytoplankton biomass at LDB.

\subsection{Distributions of bacterioplankton and HNF}

$\mathrm{Z}_{\mathrm{e}}$-integrated bacterial abundances ranged from $417 \times 10^{11}$ to $661 \times 10^{11}$ cells m$^{-2}$ at LDA and LDB, respectively (Table 1). Despite this range, there was relatively little variation when comparing biogeochemical regions; while average $\mathrm{Z}_{\mathrm{e}}-$ integrated abundances at GY were somewhat elevated compared to those for MA, and while those at LDB were amongst the highest on the transect, these differences were not statistically significant. Examining HNA and LNA subpopulations, $\mathrm{Z}_{\mathrm{e}}$-integrated abundances for HNA bacteria ranged from $115 \times 10^{11}$ to $291 \times 10^{11}$ cells m ${ }^{-2}$ at SD3 and SD9, respectively, while values for LNA ranged from $155 \times 10^{11}$ at SD3 to $298 \times 10^{11}$ cells $\mathrm{m}^{-2}$ at SD8. As with total bacteria, there were no statistically significant longitudinal differences in $\mathrm{Z}_{\mathrm{e}}$-integrated HNA or LNA abundances when comparing different biogeochemical regions. The fraction of HNA to total bacteria (\%HNA) ranged from $41.1 \pm 2.1$ to $48.0 \pm 4.9 \%$ between GY and LDB, respectively. Values for $\%$ HNA were significantly greater at LDB relative to MA and GY (ANOVA, $p<0.01$ ) and at MA relative to GY (ANOVA, $p<0.01$ ). Bacterial abundances showed less variability with depth than did phytoplankton groups, with there being no significant differences in depth-integrated abundances between $Z_{u}$ and $Z_{1}$ for total bacteria, HNA, or LNA. Depth profiles of \%HNA, however, were more variable than those for total bacteria. \%HNA increased from the surface to $\mathrm{PAR}_{0.1}$ across all biogeochemical regions, and distinct local minima were apparent near the DCM at MA and GY (Fig. 5).

Mean HNF abundances in $Z_{\mathrm{u}}$ ranged from $0.38 \times 10^{3}$ to $2.3 \times 10^{3}$ cells mL $\mathrm{mL}^{-1}$ at SD 15 and $\mathrm{LDB}$, respectively. $\mathrm{Z}_{\mathrm{e}^{-}}$ integrated abundances at LDB were significantly greater than those at GY (ANOVA, $p<0.01$ ), although no significant differences were found between other conditions. Depthintegrated abundances of HNF were significantly greater in $Z_{\mathrm{u}}$ than $\mathrm{Z}_{\mathrm{l}}$ at MA and GY (ANOVA, $p<0.01$ ), while there was no significant change in HNF abundances with depth at LDB.

\subsection{Bottom-up vs. top-down control of microbial communities}

In order to assess the roles of top-down and bottom-up control over microbial group abundances along the transect, we used a combination of approaches based on previously published models. The model described by Gasol (1994) was used to assess top-down vs. bottom-up control of HNF abundance (Fig. 6). Specifically, this approach compares observed ratios of bacteria to HNF with HNF abundance maxima estimated from empirical data and theoretical interactions between bacteria and HNF. The main assumption of the model is that bacteria to HNF ratios nearer to theoretical maxima imply increased bottom-up control of HNF by bacterial abundance. This difference is quantified with the parameter $d$, which is calculated as the difference between theoretical 

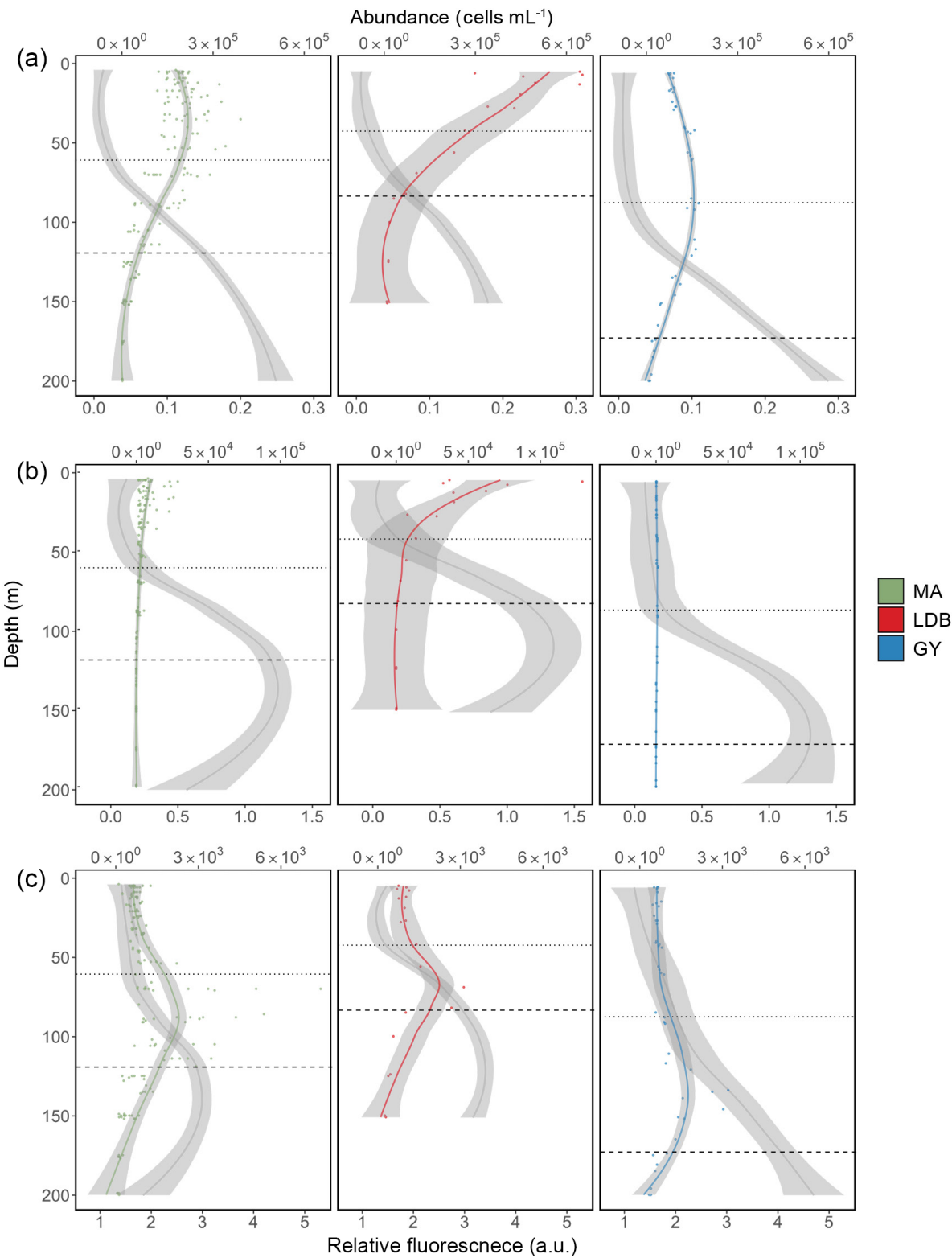

Figure 3. Abundance profiles for Prochlorococcus (a), Synechococcus (b), and PPE (c). Color-coded lines represent average cell abundance; grey lines represent the relative fluorescence for each group, based on cytometry data. Color-coded points represent original observations for biogeochemical region (MA, LDB, and GY) with shading representing standard error. Dotted and dashed horizontal lines represent average $\mathrm{PAR}_{2.7}$ and $\mathrm{PAR}_{0.1}$ depths, respectively.

and observed HNF abundances. Small values of $d$ are thus interpreted as being indicative of top-down control on bacterial populations by HNF, or by a significant use of resources other than bacteria by HNF. Large values of $d$ are interpreted as being indicative of a decoupling between the two groups, and/or a top-down control of HNF by their predators, like ciliates. Average $\mathrm{Z}_{\mathrm{u}}$ values for $d$ were $0.59 \pm 0.11,0.62 \pm 0.19$, and $0.80 \pm 0.09$ for MA, LDB, and GY, respectively. By contrast, average $Z_{1}$ values for $d$ were $0.46 \pm 0.14,0.43 \pm 0.08$, and $0.45 \pm 0.10$ for MA, LDB, and GY, respectively. $Z_{\mathrm{u}}$ Values for $d$ were significantly elevated at GY relative to MA and LDB (ANOVA, $p<0.01$ ). No significant differences in $d$ were identified between biogeochemical regions in $\mathrm{Z}_{1}$.

Regressions between abundances of bacteria and HNF were measured for $Z_{u}$ and $Z_{1}$ across biogeochemical conditions (data not shown). The variability in HNF abundances explained by bacteria abundance was generally greater in $\mathrm{Z}_{\mathrm{l}}$ compared to $\mathrm{Z}_{\mathrm{u}} \cdot \mathrm{Z}_{\mathrm{u}}$ bacterial abundances explained 24, 30, and $30 \%$ of variability in HNF abundance at MA, LDB, and GY, respectively. In $Z_{1}$, bacterial abundances explained 57 and $72 \%$ of variability at MA and GY stations, respectively, while this relationship was not statistically significant 


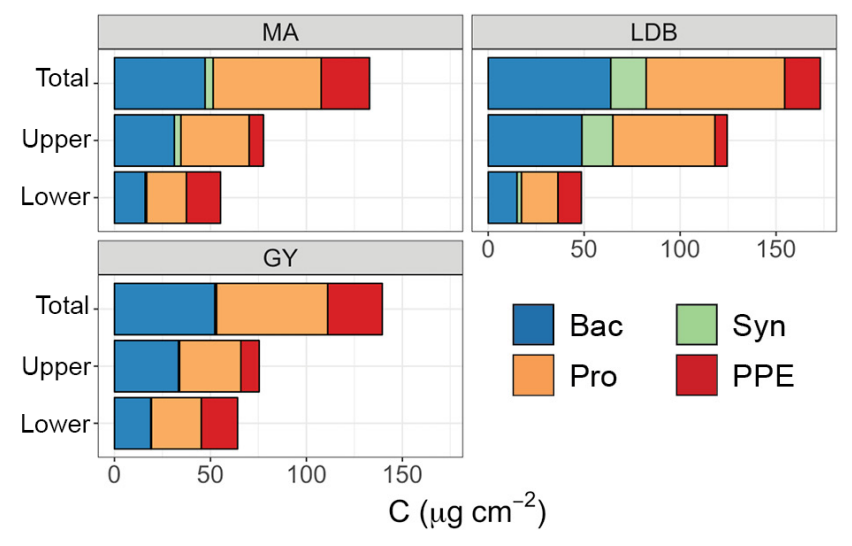

Figure 4. Contribution of different plankton groups (heterotrophic bacteria (Bac, blue), Synechococcus (Syn, green), Prochlorococcus (Pro, orange), and picophytoeukaryotes (PPE, red)) to depthintegrated biomass, averaged by biogeochemical region (MA, LDB, $\mathrm{GY})$. The $y$ axis corresponds to a layer of the euphotic zone, with "total" representing integrations from surface to PAR $_{0.1}$, "upper" representing integrations from surface to $\mathrm{PAR}_{2.7}$, and "lower" referring to depths between $\mathrm{PAR}_{2.7}$ and $\mathrm{PAR}_{0.1}$.

at LDB. Repeating this procedure for HNA bacteria alone, $\mathrm{Z}_{\mathrm{u}}$ HNA abundances were found to explain 15, 29, and $73 \%$ of variability in HNF abundance at MA, LDB, and GY, respectively. $Z_{1}$ bacteria abundances were found to explain $61 \%$ of variability in HNF populations at GY, while relationships at MA and LDB were insignificant. $Z_{\mathrm{u}}$ values for \%HNA explained $73 \%$ of variability in HNF abundances at GY, while this relationship was weak and insignificant at MA and LDB.

Using the ciliate abundances collected by Dolan et al. (2016) during the OUTPACE cruise, ratios of depthintegrated abundances of ciliates to HNF (with HNF abundances multiplied by $10^{11}$ for readability) were found to range from 2.8 in the upper euphotic zone at LDB to 17.6 in the lower euphotic zone at LDC (Fig. 2e). In the upper euphotic zone, this ratio increased from 2.9 at LDB to 10.0 at LDC and 10.9 at LDA. The lower euphotic zone showed a slightly different pattern, with the ratio increasing from 9.0 at LDA to 9.6 at LDB and 17.5 at LDC. Because data available were limited to one set of measurements at each of those three stations, it was not possible to determine whether differences in these results were statistically significant. However, comparing differences between biogeochemical conditions based on observations at individual depths, rather than depth-integrated values, indicated the ratio of ciliates to HNF to be significantly lower at LDB compared to LDC (ANOVA, $p<0.01$ ). Differences between other biogeochemical conditions, however, were statistically insignificant. No significant vertical or longitudinal differences were identified for ratios of HNF to cyanobacteria, nor for ratios of bacteria to cyanobacteria.

\subsection{Distribution of pigments and photo acclimation in different phytoplankton groups}

Phytoplankton group-specific relative fluorescence values obtained by flow cytometry for Prochlorococcus, Synechococcus, and PPE showed significant $(t$-test, $p<0.01)$ increases with depth across all biogeochemical conditions (Fig. 3). Phytoplankton relative fluorescence for all groups showed little variation within the $\mathrm{Z}_{\mathrm{u}}$, although marked increases occurred in the region of $\mathrm{PAR}_{2.7}$. Prochlorococcus relative fluorescence showed a continuous increase to $200 \mathrm{~m}$ at MA and GY, and an increase to $150 \mathrm{~m}$ at LDB. Synechococcus and PPE showed clear maxima near or just below $\mathrm{PAR}_{0.1}$, although PPE relative fluorescence showed a continuous increase to $200 \mathrm{~m}$ at $\mathrm{GY}$.

Analysis of HPLC pigment data using the approach described in Vidussi et al. (2001) largely mirrored our flow cytometry results. Transect-wide, zeaxanthin and chlorophyll $b$ pigments corresponding to cyanobacteria and prochlorophytes dominated in $Z_{u}$, accounting for $80 \pm 5.1 \%$ of total diagnostic pigments. Fucoxanthin and peridinin, diagnostic of diatoms and dinoflagellates, accounted for $3.8 \pm 1.0 \%$. Concentrations of $19^{\prime} \mathrm{HF}$ and $19^{\prime} \mathrm{BF}$ - diagnostic pigments typically used to assess abundances of prymnesiophytes and chrysophytes/pelagophytes, respectively (Wright and Jeffrey, 2006) - showed significant horizontal and vertical variability (Table 3). Absolute concentrations of both pigments showed significant increases with depth at MA and GY (ANOVA, $p<0.01$ ), although increases at LDB were not statistically significant. Ratios of $19^{\prime} \mathrm{HF}: \mathrm{Chl} a$ were significantly greater than those of $19^{\prime} \mathrm{BF}$ : Chl $a$ across all biogeochemical conditions $(t$-test, $p<0.01)$. Ratios of $19^{\prime} \mathrm{HF}$ : Chl $a$ showed significant increases with depth at MA (ANOVA, $p<0.01$ ), although increases at GY and LDB were not statistically significant. Ratios of $19^{\prime} \mathrm{BF}: T \mathrm{Chl} a$ showed significant increases at MA and GY (ANOVA, $p<0.01$ ), while increases at LDB were insignificant. $\mathrm{Z}_{1}$ ratios of $19^{\prime} \mathrm{HF}: 19^{\prime} \mathrm{BF}$ were significantly elevated at LDB compared to MA (ANOVA, $p<0.01$ ). That no similar such difference was observed in comparing LDB to GY is likely the result of the reduced number of samples available for making this comparison. Indeed, the difference was nearly significant (ANOVA, $p=0.03$ ), while $Z_{1}$ ratios of $19^{\prime} \mathrm{HF}: 19^{\prime} \mathrm{BF}$ at MA were remarkably similar (ANOVA, $p=0.99$ ). A moderately strong relationship was identified between carotenoid concentrations and PPE abundances, with variability in PPE accounting for $46 \%$ of variability in $19^{\prime} \mathrm{BF}+19^{\prime} \mathrm{HF}(p<0.01)$. 


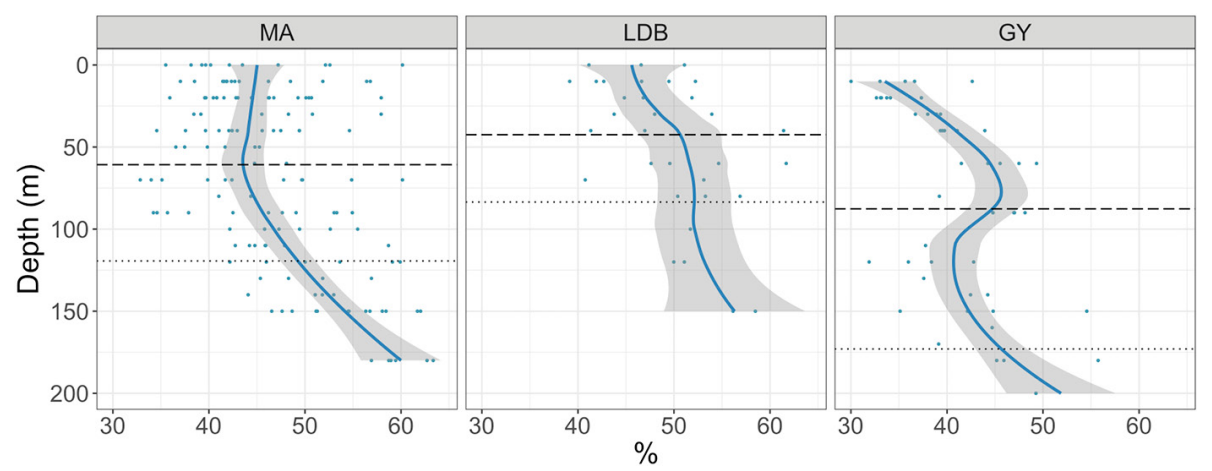

Figure 5. Percent of total bacteria accounted for by HNA, by biogeochemical region: MA, LDB, and GY. Trendline calculated using LOESS regression. Shading represents the standard error of samples at each depth. The dashed line represents the average PAR 2.7 depth. The dotted line represents the average $\mathrm{PAR}_{0.1}$ depth.

Table 3. Average depth-integrated concentrations of $19^{\prime}$-hexanoyloxyfucoxanthin $\left(19^{\prime} \mathrm{HF}\right)$ and $19^{\prime}$-butanoyloxyfucoxanthin $\left(19^{\prime} \mathrm{BF}\right)$. Ratios of these pigments to Chl $a$ calculated using HPLC values for TChl $a$.

\begin{tabular}{llccccc}
\hline cond. & zone & $19^{\prime} \mathrm{BF} \mathrm{mg} \mathrm{m}^{-3}$ & $19^{\prime} \mathrm{HF} \mathrm{mg} \mathrm{m}^{-3}$ & $19^{\prime} \mathrm{BF} / \mathrm{Chl} a$ & $19^{\prime} \mathrm{HF} / \mathrm{Chl} a$ & $19^{\prime} \mathrm{HF} / 19^{\prime} \mathrm{BF}$ \\
\hline \multirow{2}{*}{$\mathrm{MA}$} & $\mathrm{Z}_{\mathrm{u}}$ & $0.005 \pm 0.007$ & $0.021 \pm 0.014$ & $0.037 \pm 0.037$ & $0.156 \pm 0.060$ & $5.9 \pm 2.6$ \\
& $\mathrm{Z}_{1}$ & $0.040 \pm 0.021$ & $0.057 \pm 0.031$ & $0.171 \pm 0.058$ & $0.240 \pm 0.041$ & $1.6 \pm 0.7$ \\
$\mathrm{LDB}$ & $\mathrm{Z}_{\mathrm{u}}$ & $0.003 \pm 0.002$ & $0.022 \pm 0.002$ & $0.018 \pm 0.016$ & $0.124 \pm 0.049$ & $9.0 \pm 3.0$ \\
& $\mathrm{Z}_{1}$ & $0.011 \pm 0.004$ & $0.036 \pm 0.006$ & $0.053 \pm 0.011$ & $0.186 \pm 0.011$ & $3.6 \pm 0.9$ \\
& $\mathrm{Z}_{\mathrm{u}}$ & $0.003 \pm 0.003$ & $0.012 \pm 0.007$ & $0.064 \pm 0.018$ & $0.254 \pm 0.026$ & $4.2 \pm 1.2$ \\
& $\mathrm{Z}_{1}$ & $0.024 \pm 0.010$ & $0.037 \pm 0.010$ & $0.170 \pm 0.051$ & $0.271 \pm 0.051$ & $1.7 \pm 0.5$ \\
\hline
\end{tabular}

\section{Discussion}

\subsection{Distribution of phytoplankton populations in the WTSP and relative contribution to biomass}

Transect-wide biogeochemical conditions captured by our data were similar to those of the "typical tropical structure" described by Herbland and Voituriez (1979), featuring large abundances of pico-sized organisms in $\mathrm{Z}_{\mathrm{u}}$, a deep nitracline, and a prominent DCM in $Z_{1}$. Differences in relative abundances of phytoplankton groups between $Z_{u}$ and $Z_{1}$ showed a clear two-tiered vertical niche partition, with Prochlorococcus and Synechococcus reaching maximum abundances in the $\mathrm{Z}_{\mathrm{u}}$ and PPE achieving maximum abundances in the $\mathrm{Z}_{1}$. This vertical distribution has been well documented in other regions, and is thought to be characteristic of highly stratified oligotrophic systems (Dore et al., 2008; Painter et al., 2014; Partensky et al., 1996). Based on estimates from HPLC data, larger organisms such as diatoms and dinoflagellates were present in very low abundance along the transect, in comparison to small-sized phytoplankton.

Although the use of different conversion factors for estimating per-cell carbon makes it difficult to compare between different studies, our biomass estimates largely agree with those reported for other oligotrophic regions (Grob et al., 2007b; Partensky et al., 1996; Pérez et al., 2006; Zubkov et al., 2000). Prochlorococcus accounted for the large ma- jority of phytoplankton biomass in the $\mathrm{Z}_{\mathrm{u}}$, with Synechococcus and PPE only making relatively minor contributions. In $\mathrm{Z}_{1}$, by contrast, PPE accounted for a more sizeable and occasionally dominant share of phytoplankton biomass. This effect was particularly pronounced at GY, where increases in $\mathrm{Z}_{1}$ PPE biomass compensated for reductions in $\mathrm{Z}_{\mathrm{u}}$ Prochlorococcus biomass, resulting in $\mathrm{Z}_{\mathrm{e}}$ biomass totals being similar to those at MA.

To compare our results to those from other ocean basins, we conducted a meta-analysis of datasets reporting Prochlorococcus, Synechococcus, and PPE abundances alongside $\mathrm{Chl} a$ concentrations. Mean depth-integrated abundances of Synechococcus and PPE measured along the OUTPACE transect were similar to those reported elsewhere, as were those of Prochlorococcus at MA and GY (Table 4). However, mean depth-integrated abundances of Prochlorococcus at LDB were considerably higher than mean values for other regions. Some of this variation may result from the instrumentation used, with earlier cytometers generally being thought to underestimate weakly fluorescent Prochlorococcus cells near the surface. Regardless, with $\mathrm{Z}_{\mathrm{e}}$-integrated Prochlorococcus abundances at LDB being greater than any others encountered in the literature, these results highlight the importance of transient, localized blooms to cyanobacterial abundance in the region. 
Table 4. Mean depth-normalized abundances for Prochlorococcus (Pro), Synechococcus (Syn), picophytoeukaryotes (PPE), and depthintegrated concentration of $\mathrm{Chl} a$.\%pro calculated as $\mathrm{pro} /($ pro $+s y n+p p e)$. Values for different biogeochemical conditions sampled during the OUTPACE transect in bold. Depth-normalized values provided to account for differences in the depth of integration between sampling sites (data not shown). OUTPACE Chl $a$ values correspond to discrete fluorometric data collected at each station of the transect, with the exception of SD 1-3. Chl $a$ values from other datasets correspond to discrete fluorometric or HPLC data.

\begin{tabular}{lrrrrrll}
\hline area & $n$ & Chl $a \mathrm{mg} \mathrm{m}^{-3}$ & Pro $\times 10^{11} \mathrm{~m}^{-3}$ & Syn $\times 10^{11} \mathrm{~m}^{-3}$ & PPE $\times 10^{11} \mathrm{~m}^{-3}$ & $\%$ Pro & source \\
\hline LDB & $\mathbf{3}$ & $\mathbf{0 . 3 4} \pm \mathbf{0 . 0 6}$ & $\mathbf{2 . 2 3} \pm \mathbf{0 . 9 0}$ & $\mathbf{0 . 1 6} \pm \mathbf{0 . 0 7}$ & $\mathbf{0 . 0 1} \pm \mathbf{0 . 0 0}$ & $\mathbf{9 2}$ & This study \\
Indian Ocean & 28 & $0.26 \pm 0.05$ & $0.12 \pm 0.21$ & $0.08 \pm 0.06$ & $0.02 \pm 0.01$ & 25 & JGOFS $^{1}$ \\
MA & $\mathbf{1 0}$ & $\mathbf{0 . 2 3} \pm \mathbf{0 . 0 5}$ & $\mathbf{1 . 2 0} \pm \mathbf{0 . 3 4}$ & $\mathbf{0 . 0 2} \pm \mathbf{0 . 0 2}$ & $\mathbf{0 . 0 1} \pm \mathbf{0 . 0 0}$ & $\mathbf{9 7}$ & This study \\
Arabian Sea & 82 & $0.18 \pm 0.07$ & $0.47 \pm 0.46$ & $0.23 \pm 0.17$ & $0.03 \pm 0.02$ & 53 & JGOFS \\
N. Pacific & 227 & $0.15 \pm 0.02$ & $1.27 \pm 0.40$ & $0.01 \pm 0.01$ & $0.01 \pm 0.00$ & 99 & HOT $^{2}$ \\
N. Atlantic & 219 & $0.14 \pm 0.06$ & $0.48 \pm 0.34$ & $0.07 \pm 0.08$ & $0.01 \pm 0.01$ & 81 & BATS $^{3}$ \\
& & & & & & AMT $^{4}$ \\
Eq. Pacific & 212 & $0.14 \pm 0.04$ & $1.43 \pm 0.54$ & $0.11 \pm 0.06$ & $0.05 \pm 0.03$ & 93 & JGOFS \\
S. Pacific & 50 & $0.12 \pm 0.04$ & $1.00 \pm 0.34$ & $0.07 \pm 0.06$ & $0.03 \pm 0.02$ & 93 & BiG RAPA $^{5}$ \\
& & & & & & BIOSOPE $^{6}$ \\
& & & & & & JGOFS \\
Med. & 16 & $0.10 \pm 0.07$ & $0.33 \pm 0.10$ & $0.09 \pm 0.09$ & $0.02 \pm 0.01$ & 78 & JGOFS \\
GY & $\mathbf{6}$ & $\mathbf{0 . 1 1} \pm \mathbf{0 . 0 1}$ & $\mathbf{1 . 0 8} \pm \mathbf{0 . 1 0}$ & $\mathbf{0 . 0 2} \pm \mathbf{0 . 0 2}$ & $\mathbf{0 . 0 1} \pm \mathbf{0 . 0 0}$ & $\mathbf{9 9}$ & This study \\
S. Atlantic & 28 & $0.07 \pm 0.04$ & $1.21 \pm 0.32$ & $0.02 \pm 0.02$ & $0.01 \pm 0.01$ & 98 & AMT \\
\hline
\end{tabular}

1 Joint Global Ocean Flux Study (Sieger et al., 2005). ${ }^{2}$ Hawaii Ocean Time-series; HOT-Data Organization and Graphical System,

http://hahana.soest.hawaii.edu/hot/hot-dogs (last access: 7 May 2018). ${ }^{3}$ Bermuda Atlantic Time-series, http://bats.bios.edu/bats-data/ (last access: 7 May 2018).

4 Atlantic Meridional Transect; British Oceanographic Data Centre, http://www.bodc.ac.uk/ (last access: 7 May 2018). ${ }^{5}$ C-MORE Data System,

http://hahana.soest.hawaii.edu/cmoreDS (last access: 7 May 2018). ${ }^{6}$ LEFE-CYBER Database, http://www.obs-vlfr.fr/proof/ (last access: 7 May 2018).

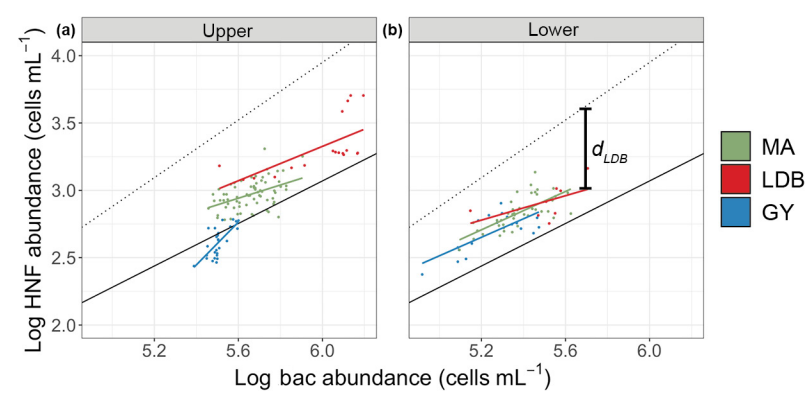

Figure 6. $\mathrm{Log}-\log$ plot of $\mathrm{Z}_{\mathrm{u}}$ bacteria and HNF abundances (upper, a) and $\log -\log$ plot of $Z_{1}$ bacteria and HNF abundances (lower, b). Dots correspond to observed abundances, grouped by condition. Solid color-coded lines are regressions for abundance data corresponding to each biogeochemical condition. The solid black line corresponds to the regression line for mean realized abundances in marine environments $(\log \mathrm{MRA}=0.79 \times \log \mathrm{Bac}-1.67)$. The dotted line corresponds to the theoretically maximum attainable abundance $(\log \mathrm{MAA}=1.07 \times \log \mathrm{Bac}-2.47)$, as described in Gasol et al. (1994). $d_{\mathrm{LDB}}$ included for clarification of the $d$ parameter.

The observed increase in the percentage of $\mathrm{Z}_{\mathrm{e}}$-integrated Prochlorococcus abundances accounting for total picophytoplankton abundance from LDB to GY captures a global trend. The proportion of Prochlorococcus cells accounting for total picophytoplankton abundances has generally been reported to decrease with increased Chl $a$ concentrations, while those of Synechococcus cells have been found to increase along the same gradient (Table 4). In the Sargasso Sea, where winter mixing allows for the resupply of surface nutrients, long-term studies have captured this relationship as a seasonal pattern, with ratios of Prochlorococcus to Synechococcus increasing inversely with changes in the depth of the nitracline (Campbell et al., 1998; Durand et al., 2001). The same phenomenon has been reported along biogeochemical conditions in the North Atlantic (Partensky et al., 1996; Zubkov et al., 2000), as well as the southeastern Pacific (Grob et al., 2007a; Rii et al., 2016b). By contrast, sites with comparatively limited seasonal variability, like station ALOHA in the North Pacific subtropical gyre, have shown consistently high ratios of Prochlorococcus to Synechococcus year-round (Rii et al., 2016a), while studies of nitraterich eutrophic regions often report the complete exclusion of Prochlorococcus by Synechococcus and eukaryotic populations (Sherr et al., 2005; Zubkov et al., 2007). The high relative abundance of Prochlorococcus at LDB compared to sites with similar Chl $a$ concentrations may be due to having captured the bloom in decay (de Verneil et al., 2017), with nutrients having been largely depleted at the time of measurement and relative Prochlorococcus abundances returning to levels more representative of the WTSP. Alternatively, the bloom conditions may be incomparable to regions with more persistent inputs of nutrients. 


\subsection{Potential factors regulating the horizontal distribution of phytoplankton groups}

In examining the potential factors regulating the distribution and abundance of cyanobacterial groups, our data did not reward any expectations that abundances of Prochlorococcus, Synechococcus or PPE would correlate meaningfully with $\mathrm{NO}_{x}$ concentrations. While negative relationships were identified between plankton abundances and $\mathrm{NO}_{x}$ concentrations across all sites, this was likely the result of changes in these parameters with depth rather than being indicative of any causal relationship. Indeed, comparing values in $\mathrm{Z}_{\mathrm{u}}$ alone, correlations between $\mathrm{NO}_{x}$ and plankton abundances became insignificant, with $\mathrm{NO}_{x}$ being largely depleted above $\mathrm{PAR}_{2.7}$. However, correlations between $\mathrm{N}_{2}$ fixation, $\mathrm{PO}_{4}$ concentrations, and plankton abundances persisted even when subsetting data to only include measurements within the mixed layer, indicating covariation between these parameters as occurring independently of depth. Specifically, correlations between $\mathrm{N}_{2}$ fixation rates and abundances of cyanobacteria suggest plankton abundances in the surface to respond to diazotroph-derived nitrogen (ammonia and DON) provided by $\mathrm{N}_{2}$-fixing organisms, notably Trichodesmium which dominated in the upper euphotic zone at MA (Stenegren et al., 2018). Previous studies have demonstrated growth to increase with DON enrichment in both Synechococcus and Prochlorococcus cultures (Moore et al., 2002), while others have indicated that diazotrophs may provide a large enough input of fixed nitrogen to sustain large populations of cyanobacteria (Bonnet et al., 2016b). Moreover, previous experiments in the New Caledonia lagoon have shown a rapid transfer $(24-48 \mathrm{~h}$ ) of recently fixed $\mathrm{N}$ by Trichodesmium towards non-diazotrophic phytoplankton and heterotrophic bacteria (Bonnet et al., 2016a), while Caffin et al. have demonstrated the efficient transfer of $\mathrm{N}$ fixed by UCYN-B cyanobacteria to the planktonic food web along the OUTPACE transect (2018). Biological nitrogen inputs may allow for a more complete utilization of $\mathrm{PO}_{4}$ at sites featuring high nitrogen-fixation rates (Mather et al., 2008; Moutin et al., 2018), accounting for the negative correlations observed between $\mathrm{PO}_{4}$ concentrations and abundances of Prochlorococcus and Synechococcus, as well as for the negative correlations observed between $\mathrm{PO}_{4}$ concentrations and $\mathrm{N}_{2}$ fixation rates. These results, along with the low DIP turnover rates reported, suggest intense competition for phosphorus within the mixed layer, and a rapid transfer of fixed $\mathrm{N}$ toward prokaryotes (Van Wambeke et al., 2018).

\subsection{Potential factors regulating vertical variability in phytoplankton community structure}

Considerable variation in vertical distributions of phytoplankton groups was observed between biogeochemical regions. Although Synechococcus and PPE appeared confined to high-light and low-light depths, respectively, Prochloro- coccus abundances showed a greater deal of vertical variability, with Prochlorococcus subsurface abundance maxima varying widely with respect to PAR (Fig. 3). This indicates Prochlorococcus distributions in $\mathrm{Z}_{\mathrm{u}}$ to be less sensitive to changes in light availability than other phytoplankton groups (Partensky et al., 1999), possibly as a result of comparatively reduced increases in per-cell chlorophyll concentrations with depth, as reflected by relative fluorescence values (Fig. 3). However, the observed Prochlorococcus distributions reflect the average distribution of a mosaic of different ecotypes encompassing high diversity in their response to nutrients, light, and temperature (Johnson, 2006; Kashtan et al., 2014; Moore et al., 2002). Indeed, the increase in depth of Prochlorococcus abundance maxima observed at GY is likely the result of the deepening of the euphotic layer, combined with the reduction of high-light ecotypes in $Z_{\mathrm{u}}$. While previous studies have reported correlations between Prochlorococcus abundance maxima and nitracline depth (Li, 1995; Olson et al., 1990), no such similar patterns were observed in our data. These distributions may be a transient feature formed during restratification following winter mixing (Partensky et al., 1999), and are unlikely to be in response to nitrate availability, given the small nitrate utilization by Prochlorococcus in natural samples (Casey et al., 2007). These results may also be the consequence of the difficulty in detecting weakly fluorescent high-light Prochlorococcus following earlier flow cytometry protocols with less sensitive instruments.

In contrast to other phytoplankton groups, PPE abundances were marginal in $Z_{u}$, but increased dramatically below $\mathrm{PAR}_{10}$, reaching maximal abundances at depths closely correlated with those of the DCM. The lack of variability of PPE abundance maxima relative to PAR, along with the decoupling of PPE maxima from the nitracline at LDB, suggest PPE abundances to be primarily controlled by light levels rather than by the availability of dissolved nutrients. However, it is difficult to consider these factors independently, with the increased chlorophyll concentrations required at low light levels likely increasing nitrogen requirements on shadeadapted organisms (Edwards et al., 2015).

Differences in vertical distributions of PPE between stations likely also reflect variability in the composition of PPE communities. The decrease with depth observed in ratios of $19^{\prime} \mathrm{HF}: 19^{\prime} \mathrm{BF}$ would suggest that prymnesiophytes dominate in the $\mathrm{Z}_{\mathrm{u}}$, with chrysophytes and pelagophytes accounting for a greater proportion of total PPE abundance in $\mathrm{Z}_{1}$. Similar distributions have been reported elsewhere, and have been suggested to reflect control of chrysophyte and pelagophyte abundances by nitrate availability (Barlow et al., 1997; Claustre et al., 1994; Marty et al., 2002). This interpretation agrees with our results, where the separation of PPE abundance maxima from the nitracline coincided with significantly elevated $Z_{1}$ ratios of $19^{\prime} \mathrm{HF}: 19^{\prime} \mathrm{BF}$ compared to MA. That elevated $Z_{1}$ values for $19^{\prime} \mathrm{HF}: 19^{\prime} \mathrm{BF}$ at LDB coincide with transect-wide maximal concentrations 
of NH4 suggests that prymnesiophytes may preferentially utilize reduced forms of nitrogen. This would also account for the elevated abundances of this group in $\mathrm{Z}_{\mathrm{u}}$ across all biogeochemical conditions, where reduced forms of nitrogen would generally be expected to be more abundant as a result of nutrient recycling. Admittedly, with variability in $19^{\prime} \mathrm{HF}+19^{\prime} \mathrm{BF}$ only accounting for $\sim 50 \%$ of variability in picoeukaryote abundances, it is likely that observed patterns of $19^{\prime} \mathrm{HF}: 19^{\prime} \mathrm{BF}$ capture changes in nano- and micro-sized eukaryotes in addition to PPE.

It is also possible that $Z_{1}$ PPE populations are responding to the availability of nitrogen fixed by UCYN-A cyanobacteria, which were reported to have distributions at least qualitatively similar to those of PPE across the transect (Stenegren et al., 2018). Several UCYN-A clades have been identified to form symbioses with small prymnesiophytes, including at least one pico-sized haptophyte (Martínez-Pérez et al., 2016), making it seem plausible that such relationships could play an important role in controlling PPE distributions.

\subsection{Factors controlling bacterial abundance and the role of HNF}

Average bacterioplankton abundances in the $\mathrm{Z}_{\mathrm{e}}$ $\left(3.6 \times 10^{8} \pm 2.6 \times 10^{5}\right.$ cells L $\left.^{-1}\right)$ were within the established range of $1-5 \times 10^{8}$ cells $L^{-1}$ for the oligotrophic ocean (Ducklow, 2002). That bacterioplankton abundances at LDB should exceed this range, slightly exceeding $7.0 \times 10^{8}$ cells $\mathrm{L}^{-1}$, is not surprising, based on the increased abundances of phytoplankton at that station. Surface values for \% HNA, ranging from $30 \%$ at SD15 to $51 \%$ at SD1, are similar to previously reported values, as is the observed increase in \%HNA with depth (Van Wambeke et al., 2011). The reduced values for \%HNA reported for GY are similar to those reported for other nutrient-limited regions, and may be the result of LNA cells being capable of more rapid growth than HNA under nutrient limitation (Andrade et al., 2007; Nishimura et al., 2005).

To assess variation in trophic interactions between HNF and bacteria across biogeochemical conditions, we used the method presented by Gasol (1994), which compares observed ratios of HNF to bacteria with theoretical maxima (d). Previous applications of this model have demonstrated an increase in top-down control of bacterial populations in low-chlorophyll regions, demonstrated by low values for $d$ under nutrient limitation (Gasol et al., 2002). These results find general support in the literature, on the underlying assumption that nutrient-limited regions are characterized by reduced abundances of top predators, resulting in increased grazing pressure on bacteria via a trophic cascade (Pernthaler, 2005). Our data, however, contrast with these conclusions, with values for $d$ being significantly greater at GY relative to those corresponding to MA or LDB, suggesting a reduction in grazing pressure on heterotrophic bacteria with increased nutrient limitation in $\mathrm{Z}_{\mathrm{u}}$.
There are several possible explanations for this result. Based on the significantly reduced $\mathrm{Z}_{\mathrm{u}}$ values for $\% \mathrm{HNA}$ encountered at GY, decoupling of bacterial and HNF populations may be the result of diminished prey quality at these sites. While it has been debated whether HNA and LNA can be interpreted as representing active and inactive cells, respectively (Jochem et al., 2004; Vaqué et al., 2001), HNA bacteria have generally been found to be larger in diameter than LNA bacteria (Van Wambeke et al., 2011), possibly making them more susceptible to grazing. Such a phenomenon has been described previously in nutrient-limited regions (Longnecker et al., 2010; Vaqué et al., 2001), although studies conducted in relatively nutrient-rich regions have reported no such similar evidence (Jochem et al., 2004). In our data, the increased $r^{2}$ values for linear regressions between abundances of HNA and HNF at GY suggest that HNA densities may be more important in controlling HNF densities at GY than at MA or LDB. This may account for the increased values of $d$ calculated at GY - the relationships used to establish the model's theoretical maxima not accounting for changes in grazing rates in response to \%HNA, and thereby potentially overestimating HNF abundance, as derived from bacterial abundance, in cases where \%HNA is low. Plotting bacterial abundances against the bacterial production data reported by Van Wambeke et al. (2018), and interpreting regression slopes using the criteria described by Ducklow et al. (1992) in $Z_{u}$, we found no evidence of bottom-up control of bacteria populations at MA, LDB or GY (data not shown). This is similar to the results obtained by Morán et al. (2017), who applied the Ducklow model to data collected in the South Pacific during austral summer and reported very weak bottom-up control at all sampling sites, calculating regression slopes around 0.2 for samples between the surface and $4000 \mathrm{~m}$. The authors likely would have obtained still lower slopes had their analysis been restricted to surface data alone, as we found for $\mathrm{Z}_{\mathrm{u}}$.

The increase in $d$ at GY could alternatively result from increased grazing on cyanobacterial prey, given that the HNF abundances predicted by the Gasol model are calculated on the assumption that HNF only graze on heterotrophic bacteria. Previous studies have reported HNF to graze on cyanobacteria, generally at rates similar to those reported for grazing on heterotrophic bacteria (Christaki, 2001; Cuevas and Morales, 2006; Ferrier-Pagès and Gattuso, 1998). However, ratios of bacteria to cyanobacteria are largely invariable across the transect, as are ratios of HNF to cyanobacteria. Both of these values would reasonably be expected to vary if responsible for the reported differences in $d$. To account for the possibility that Prochlorococcus cells were erroneously identified as heterotrophic bacteria at the time of the model's formulation, we repeated the analysis including abundances of Prochlorococcus on the $x$-axis. Although doing so increased $d$ values across all biogeochemical conditions, it did not qualitatively affect the relationship as described above (data not shown). 
The reduction of $d$ reported in $\mathrm{Z}_{1}$ may result from phagotrophy by PPE, by reducing bacterial abundances relative to those of HNF. Feeding experiments in the North Atlantic have demonstrated small plastidic eukaryotes to account for up to $90 \%$ of bacterivory in nutrient-limited waters (Zubkov and Tarran, 2008), while laboratory and field studies have demonstrated increased feeding rates specifically in response to $P$ limitation (Christaki et al., 1999; McKieKrisberg et al., 2015). We also cannot exclude the possibility that the decoupling of bacterial and HNF populations observed at GY reflects increased grazing pressure on HNF by ciliates, which would imply an increase in the importance of top-down processes under nutrient limitation. However, given that ratios of ciliates to bacteria are similar between MA and GY, it does not seem likely that the significant differences in $d$ between these sites reflect a change in the interactions between these organisms.

Finally, viruses undoubtedly contribute to the observed variation in bacterial abundances, with previous studies reporting viral lysis to be an equally if not more important factor in controlling prokaryote mortality than grazing alone in the surface waters in the open ocean, with protistan grazing only becoming dominant in the DCM layer (Lara et al., 2017). Indeed, $d$ values were smaller in $Z_{1}$ (including the DCM) than in $Z_{u}$ in all three regions investigated in the WTSP. However, the relationship presented by Lara et al. (2017) between protist-mediated mortality and virusmediated mortality is very large along the $1: 1$ line, making it difficult to infer how viral lysis might have contributed to the reported differences in $d$.

\section{Conclusions}

Our results demonstrate the distribution of microorganisms in the WTSP to be qualitatively similar to those reported for other highly stratified oligotrophic regions. The entire transect length was characterized by a two-tier vertical niche partition, with Prochlorococcus and Synechococcus achieving abundance maxima in the $Z_{\mathrm{u}}$, and PPE achieving abundance maxima in the $Z_{1}$, at depths coincident with the DCM. The strong relationships between $\mathrm{N}_{2}$ fixation and primary producers demonstrate the central role of $\mathrm{N}_{2}$ fixation in regulating ecosystem processes in the WTSP, with the influence of biologically fixed nitrogen being exerted across all depths and across all classes of organisms in the study region. At MA and LDB, increases in $\mathrm{N}_{2}$ fixation rates are accompanied by increased production near the surface, and by increased abundances of Synechococcus relative to Prochlorococcus. At GY, the marked decrease in $\mathrm{N}_{2}$ fixation rates is accompanied by greatly reduced phytoplankton abundances, which may translate directly into reduced proportions of HNA bacteria. This shift is coincident with a decoupling of HNF and bacteria populations at GY, suggesting a reduction in the importance of top-down controls in regulating bacteria abun- dance under nutrient-limited conditions. In the lower euphotic zone, these changes may also influence the amount and the quality of nutrients available to PPE communities, influencing both the diversity and vertical distributions of the organisms they comprise.

Data availability. All data and metadata are available at the French INSU/CNRS LEFE CYBER database (scientific coordinator: Hervé Claustre; data manager and webmaster: Catherine Schmechtig) at the following web address: http://www.obs-vlfr. fr/proof/php/outpace/outpace.php (INSU/CNRS LEFE CYBER, 2018).

Competing interests. The authors declare that they have no conflict of interest.

Special issue statement. This article is part of the special issue "Interactions between planktonic organisms and biogeochemical cycles across trophic and $\mathrm{N}_{2}$ fixation gradients in the western tropical South Pacific Ocean: a multidisciplinary approach (OUTPACE experiment)". It is not associated with a conference.

Acknowledgements. This is a contribution of the OUTPACE project (https://outpace.mio.univ-amu.fr/, last access: 7 May 2018) funded by the French research national agency (ANR-14-CE010007-01), the LEFE-CyBER program (CNRS-INSU), the GOPS program (IRD) and the CNES. We thank Thierry Moutin and Sophie Bonnet, chief scientists of the OUTPACE cruise. We are indebted to Olivier Grosso and Sandra Helias-Nunige for nutrient measurements, to Sophie Bonnet for $\mathrm{N}_{2}$ fixation measurements, to Joséphine Ras for HPLC pigment measurements, and to Gilles Rougier and Marc Picheral for their help in CTD rosette management and data processing. We are grateful to the crew of the R/V L'Atalante for outstanding shipboard operation. The National Science Foundation (NSF) OCE-1434916 award to Solange Duhamel supported Solange Duhamel and Moïra Dion; the NSF OCE-1458070 award to Solange Duhamel supported Nicholas Bock. The acquisition of BIOSOPE data was funded through CNRS-INSU grants. This study uses data from the Atlantic Meridional Transect Consortium (NER/0/5/2001/00680), provided by the British Oceanographic Data Centre and supported by the Natural Environment Research Council.

Edited by: Sophie Bonnet

Reviewed by: two anonymous referees

\section{References}

Andrade, L., Gonzalez, A. M., Rezende, C. E., Suzuki, M., Valentin, J. L., and Paranhos, R.: Distribution of HNA and LNA bacterial groups in the Southwest Atlantic Ocean, Braz. J. Microbiol., 38, 330-336, https://doi.org/10.1590/S1517$83822007000200028,2007$. 
Barlow, R. G., Mantoura, R. F. C., Cummings, D. G., and Fileman, T. W.: Pigment chemotaxonomic distributions of phytoplankton during summer in the western Mediterranean, Deep-Sea Res. Pt. II, 44, 833-850, https://doi.org/10.1016/S0967-0645(96)000896, 1997.

Blanchot, J. and Rodier, M.: Picophytoplankton abundance and biomass in the western tropical Pacific Ocean during the 1992 El Nino year: Results from flow cytometry, Deep-Sea Res. Pt. I, 43, 877-895, https://doi.org/10.1016/0967-0637(96)00026-X, 1996.

Bonnet, S., Berthelot, H., Turk-Kubo, K., Cornet-Barthaux, V., Fawcett, S., Berman-Frank, I., Barani, A., Grégori, G., Dekaezemacker, J., Benavides, M., and Capone, D. G.: Diazotroph derived nitrogen supports diatom growth in the South West Pacific: A quantitative study using nanoSIMS, Limnol. Oceanogr., 61, 1549-1562, https://doi.org/10.1002/lno.10300, 2016a.

Bonnet, S., Moutin, T., Rodier, M., Grisoni, J. M., Louis, F., Folcher, E., Bourgeois, B., Boré, J. M., and Renaud, A.: Introduction to the project VAHINE: VAriability of vertical and tropHIc transfer of diazotroph derived $\mathrm{N}$ in the south wEst Pacific, Biogeosciences, 13, 2803-2814, https://doi.org/10.5194/bg-132803-2016, 2016b.

Bonnet, S., Caffin, M., Berthelot, H., Grosso, O., Benavides, M., Helias-Nunige, S., Guieu, C., Stenegren, M., and Foster, R. A.: In depth characterization of diazotroph activity across the Western Tropical South Pacific hot spot of $\mathrm{N}_{2}$ fixation, Biogeosciences Discuss., https://doi.org/10.5194/bg-2017-567, in review, 2018.

Brum, J. R., Ignacio-Espinoza, J. C., Roux, S., Doulcier, G., Acinas, S. G., Alberti, A., and Chaffron, S.: Ocean Viral Communities, Science, 348, 1261498, https://doi.org/10.1126/science.1261498, 2015.

Caffin, M., Berthelot, H., Cornet-Barthaux, V., Barani, A., and Bonnet, S.: Transfer of diazotroph-derived nitrogen to the planktonic food web across gradients of $\mathrm{N}_{2}$ fixation activity and diversity in the western tropical South Pacific Ocean, Biogeosciences, 15, 3795-3810, https://doi.org/10.5194/bg-15-3795-2018, 2018.

Campbell, L. and Vaulot, D.: Photosynthetic picoplankton community structure in the subtropical North Pacific Ocean near Hawaii (station ALOHA), Deep-Sea Res. Pt. I, 40, 2043-2060, https://doi.org/10.1016/0967-0637(93)90044-4, 1993.

Campbell, L., Landry, M. R., Constantinou, J., Nolla, H. A., Brown, S. L., Liu, H., and Caron, D. A.: Response of microbial community structure to environmental forcing in the Arabian Sea, DeepSea Res. Pt. II, 45, 2301-2325, https://doi.org/10.1016/S09670645(98)00072-1, 1998.

Carlson, C., del Giorgio, P., and Herndl, G.: Microbes and the Dissipation of Energy and Respiration: From Cells to Ecosystems, Oceanography, 20, 89-100, https://doi.org/10.5670/oceanog.2007.52, 2007.

Casey, J. R., Lomas, M. W., Mandecki, J., and Walker, D. E.: Prochlorococcus contributes to new poduction in the Sargasso Sea deep chlorophyll maximum, Geophys. Res. Lett., 34, 1-5, https://doi.org/10.1029/2006GL028725, 2007.

Chisholm, S. W., Olson, R. J., Zettler, E. R., Goericke, R., Waterbury, J. B., and Welschmeyer, N. A.: A novel free-living prochlorophyte abundant in the oceanic euphotic zone, Nature, 334, 340-343, https://doi.org/10.1038/334340a0, 1988.
Christaki, U.: Nanoflagellate predation on auto- and heterotrophic picoplankton in the oligotrophic Mediterranean Sea, J. Plankton Res., 23, 1297-1310, https://doi.org/10.1093/plankt/23.11.1297, 2001.

Christaki, U., Van Wambeke, F., and Dolan, J. R.: Nanoflagellates (mixotrophs, heterotrophs and autotrophs) in the oligotrophic eastern Mediterranean: Standing stocks, bacterivory and relationships with bacterial production, Mar. Ecol.-Prog. Ser., 181, 297 307, https://doi.org/10.3354/meps181297, 1999.

Christaki, U., Courties, C., Massana, R., Catala, P., Lebaron, P., Gasol, J. M., and Zubkov, M. V.: Optimized routine flow cytometric enumeration of heterotrophic flagellates using SYBR Green I, Limnol. Oceanogr.-Meth., 9, 329-339, https://doi.org/10.4319/lom.2011.9.329, 2011.

Claustre, H., Kerherve, P., Marty, J. C., Prieur, L., Videau, C., and Hecq, J. H.: Phytoplankton Dynamics Associated With a Geostrophic Front - Ecological and Biogeochemical Implications, J. Mar. Res., 52, 711-742, https://doi.org/10.1357/0022240943077000, 1994.

Cuevas, L. A. and Morales, C. E.: Nanoheterotroph grazing on bacteria and cyanobacteria in oxic and suboxic waters in coastal upwelling areas off northern Chile, J. Plankton Res., 28, 385-397, https://doi.org/10.1093/plankt/fbi124, 2006.

Denis, M., Thyssen, M., Martin, V., Manca, B., and Vidussi, F.: Ultraphytoplankton basin-scale distribution in the eastern Mediterranean Sea in winter: Link to hydrodynamism and nutrients, Biogeosciences, 7, 2227-2244, https://doi.org/10.5194/bg-7-22272010, 2010.

de Verneil, A., Rousselet, L., Doglioli, A. M., Petrenko, A. A., and Moutin, T.: The fate of a southwest Pacific bloom: gauging the impact of submesoscale vs. mesoscale circulation on biological gradients in the subtropics, Biogeosciences, 14, 3471-3486, https://doi.org/10.5194/bg-14-3471-2017, 2017.

de Verneil, A., Rousselet, L., Doglioli, A. M., Petrenko, A. A., Maes, C., Bouruet-Aubertot, P., and Moutin, T.: OUTPACE long duration stations: physical variability, context of biogeochemical sampling, and evaluation of sampling strategy, Biogeosciences, 15, 2125-2147, https://doi.org/10.5194/bg-15-2125-2018, 2018.

Dolan, J. R., Gimenez, A., Cornet-Barthaux, V., and de Verneil, A.: Community Structure of Tintinnid Ciliates of the Microzooplankton in the South East Pacific Ocean: Comparison of a High Primary Productivity with a Typical Oligotrophic Site, J. Eukaryot. Microbiol., 63, 813-822, https://doi.org/10.1111/jeu.12328, 2016.

Dore, J. E., Letelier, R. M., Church, M. J., Lukas, R., and Karl, D. M.: Summer phytoplankton blooms in the oligotrophic North Pacific Subtropical Gyre: Historical perspective and recent observations, Prog. Oceanogr., 76, 2-38, https://doi.org/10.1016/j.pocean.2007.10.002, 2008.

Ducklow, H.: Bacterial Production and Biomass in the Oceans, in: Microbial Ecology of the Ocean, edited by: Kirchman, D., 4, 147, Wiley, New York, 2002.

Ducklow, H. W.: Factors regulating bottom-up control of bacteria biomass in open ocean plankton communities, Arch. Hydrobiol. Beih. Ergebn. Limnol., 37, 207-217, 1992.

Duhamel, S., Björkman, K. M., Doggett, J. K., and Karl, D. M.: Microbial response to enhanced phosphorus cycling in the North Pacific Subtropical Gyre, Mar. Ecol.-Prog. Ser., 504, 43-58, https://doi.org/10.3354/meps10757, 2014. 
Durand, M. D., Olson, R. J., and Chisholm, S. W.: Phytoplankton population dynamics at the Bermuda Atlantic Time-series station in the Sargasso Sea, Deep-Sea Res. Pt. II, 48, 1983-2003, https://doi.org/10.1016/S0967-0645(00)00166-1, 2001.

Edwards, K. F., Thomas, M. K., Klausmeier, C. A., and Litchman, E.: Light and growth in marine phytoplankton: Allometric, taxonomic, and environmental variation, Limnol. Oceanogr., 60, 540-552, https://doi.org/10.1002/lno.10033, 2015.

Ferrier-Pagès, C. and Gattuso, J. P.: Biomass, production and grazing rates of pico- and nanoplankton in coral reef waters (Miyako Island, Japan), Microb. Ecol., 35, 46-57, https://doi.org/10.1007/s002489900059, 1998.

Field, C. B.: Primary Production of the Biosphere: Integrating Terrestrial and Oceanic Components, Science, 281, 237-240, https://doi.org/10.1126/science.281.5374.237, 1998.

Fuhrman, J. A.: Microbial community structure and its functional implications, Nature, 459, 193-199, https://doi.org/10.1038/nature08058, 2009.

Gasol, J. M.: A framework for the assessment of topdown vs bottom-up control of heterotrophic nanoflagellate abundance, Mar. Ecol.-Prog. Ser., 113, 291-300, https://doi.org/10.3354/meps113291, 1994

Gasol, J. M., Pedr, C., Pedrós-Alió, C., and Vaqué, D.: Regulation of bacterial assemblages in oligotrophic plankton systems: results from experimental and empirical approaches, Antonie van Leeuwenhoek, 81, 435-452, https://doi.org/10.1023/a:1020578418898, 2002.

Grob, C., Ulloa, O., Claustre, H., Huot, Y., Alarcón, G., and Marie, D.: Contribution of picoplankton to the total particulate organic carbon concentration in the eastern South Pacific, Biogeosciences, 4, 837-852, https://doi.org/10.5194/bg-4-8372007, 2007a.

Grob, C., Ulloa, O., Li, W. K. W., Alarcon, G., Fukasawa, M., and Watanabe, S.: Picoplankton abundance and biomass across the eastern South Pacific Ocean along latitude 32.5 degrees S, Mar. Ecol.-Prog. Ser., 332, 53-62, https://doi.org/10.3354/Meps332053, 2007b.

Huang, S., Zhang, S., Jiao, N., and Chen, F.: Marine cyanophages demonstrate biogeographic patterns throughout the global ocean, Appl. Environ. Microbiol., 81, 441-452, https://doi.org/10.1128/AEM.02483-14, 2015.

INSU/CNRS LEFE CYBER: OUTPACE - Oligotrophy to UlTraoligotrophy PACific Experiment, available at: http://www. obs-vlfr.fr/proof/php/outpace/outpace.php, last access: 7 May 2018.

Jochem, F. J., Lavrentyev, P. J., and First, M. R.: Growth and grazing rates of bacteria groups with different apparent DNA content in the Gulf of Mexico, Mar. Biol., 145, 1213-1225, https://doi.org/10.1007/s00227-004-1406-7, 2004.

Johnson, Z. I.: Niche Partitioning Among Prochlorococcus Ecotypes Along Ocean-Scale Environmental Gradients, Science, 311, 1737-1740, https://doi.org/10.1126/science.1118052, 2006.

Karl, D. M.: Minireviews: A Sea of Change: Biogeochemical Variability in the North Pacific Subtropical Gyre, Ecosystems, 2, 181-214, https://doi.org/10.1007/s100219900068, 1999.

Kashtan, N., Roggensack, S. E., Rodrigue, S., Thompson, J. W., Biller, S. J., Coe, A., Ding, H., Marttinen, P., Malmstrom, R. R., Stocker, R., Follows, M. J., Stepanauskas, R., and Chisholm, S. W.: Single-Cell Genomics Reveals Hundreds of Coexisting
Subpopulations in Wild Prochlorococcus, Science, 344, 416-20, https://doi.org/10.1126/science.1248575, 2014.

Kim, E., Sprung, B., Duhamel, S., Filardi, C., and Kyoon Shin, M.: Oligotrophic lagoons of the South Pacific Ocean are home to a surprising number of novel eukaryotic microorganisms, Environ. Microbiol., 18, 4549-4563, https://doi.org/10.1111/14622920.13523, 2016.

Lara, E., Vaqué, D., Sà, E. L., Boras, J. A., Gomes, A., Borrull, E., Díez-Vives, C., Teira, E., Pernice, M. C., Garcia, F. C., Forn, I., Castillo, Y. M., Peiró, A., Salazar, G., Morán, X. A. G., Massana, R., Catalá, T. S., Luna, G. M., Agustí, S., Estrada, M., Gasol, J. M., and Duarte, C. M.: Unveiling the role and life strategies of viruses from the surface to the dark ocean, Sci. Adv., 3, e1602565, https://doi.org/10.1126/sciadv.1602565, 2017.

Lepère, C., Vaulot, D., and Scanlan, D. J.: Photosynthetic picoeukaryote community structure in the South East Pacific Ocean encompassing the most oligotrophic waters on Earth, Environ. Microbiol., 11, 3105-3117, https://doi.org/10.1111/j.14622920.2009.02015.x, 2009.

Li, W. K.: Composition of ultraphytoplankton in the central north Atlantic, Mar. Ecol.-Prog. Ser., 122, 1-8, https://doi.org/10.3354/meps 122001, 1995.

Longnecker, K., Wilson, M. J., Sherr, E. B., and Sherr, B. F.: Effect of top-down control on cell-specific activity and diversity of active marine bacterioplankton, Aquat. Microb. Ecol., 58, 153-165, https://doi.org/10.3354/ame01366, 2010.

Martínez-Pérez, C., Mohr, W., Löscher, C. R., Dekaezemacker, J., Littmann, S., Yilmaz, P., Lehnen, N., Fuchs, B. M., Lavik, G., Schmitz, R. A., LaRoche, J., and Kuypers, M. M.: The small unicellular diazotrophic symbiont, UCYN-A, is a key player in the marine nitrogen cycle, Nat. Microbiol., 1, 1-7, https://doi.org/10.1038/nmicrobiol.2016.163, 2016.

Marty, J. C., Chiavérini, J., Pizay, M. D., and Avril, B.: Seasonal and interannual dynamics of nutrients and phytoplankton pigments in the western Mediterranean Sea at the DYFAMED timeseries station (1991-1999), Deep-Sea Res. Pt. II, 49, 1965-1985, https://doi.org/10.1016/S0967-0645(02)00022-X, 2002.

Mather, R. L., Reynolds, S. E., Wolff, G. A., Williams, R. G., Torres-Valdes, S., Woodward, E. M. S., Landolfi, A., Pan, X., Sanders, R., and Achterberg, E. P.: Phosphorus cycling in the North and South Atlantic Ocean subtropical gyres, Nat. Geosci., 1, 439-443, https://doi.org/10.1038/ngeo232, 2008.

McKie-Krisberg, Z. M., Gast, R. J., and Sanders, R. W.: Physiological Responses of Three Species of Antarctic Mixotrophic Phytoflagellates to Changes in Light and Dissolved Nutrients, Microb. Ecol., 70, 21-29, https://doi.org/10.1007/s00248-0140543-x, 2015.

Montoya, J. P., Voss, M., Kahler, P., and Capone, D. G.: A Simple, High-Precision, High-Sensitivity Tracer Assay for N (inf2) Fixation. These include: A Simple, High-Precision, High-Sensitivity Tracer Assay for N2 Fixation, Appl. Environ. Microbiol., 62, 986-993, 1996.

Moore, L. R., Post, A. F., and Rocap, G.: Utilization of different nitrogen sources by the marine cyanobacteria Prochlorococcus and Synechococcus, Limnol. Oceanogr., 47, 989-996, 2002.

Morán, X. A. G., Gasol, J. M., Pernice, M. C., Mangot, J. F., Massana, R., Lara, E., Vaqué, D., and Duarte, C. M.: Temperature regulation of marine heterotrophic prokaryotes increases latitudinally as a breach between bottom-up 
and top-down controls, Glob. Change Biol., 23, 3956-3964, https://doi.org/10.1111/gcb.13730, 2017.

Moutin, T., Doglioli, A. M., de Verneil, A., and Bonnet, S.: Preface: The Oligotrophy to the UlTra-oligotrophy PACific Experiment (OUTPACE cruise, 18 February to 3 April 2015), Biogeosciences, 14, 3207-3220, https://doi.org/10.5194/bg-143207-2017, 2017.

Moutin, T., Wagener, T., Caffin, M., Fumenia, A., Gimenez, A., Baklouti, M., Bouruet-Aubertot, P., Pujo-Pay, M., Leblanc, K., Lefevre, D., Helias Nunige, S., Leblond, N., Grosso, O., and de Verneil, A.: Nutrient availability and the ultimate control of the biological carbon pump in the western tropical South Pacific Ocean, Biogeosciences, 15, 2961-2989, https://doi.org/10.5194/bg-15-2961-2018, 2018.

Nishimura, Y., Kim, C., and Nagata, T.: Vertical and seasonal variations of bacterioplankton subgroups with different nucleic acid contents: Possible regulation by phosphorus, Appl. Environ. Microbiol., 71, 5828-5836, https://doi.org/10.1128/AEM.71.10.5828-5836.2005, 2005.

Olson, R. J., Chisholm, S. W., Zettler, E. R., Altabet, M. A., and Dusenberry, J. A.: Spatial and temporal distributions of prochlorophyte picoplankton in the North Atlantic Ocean, DeepSea Res. Pt. I, 37, 1033-1051, https://doi.org/10.1016/01980149(90)90109-9, 1990.

Painter, S. C., Patey, M. D., Tarran, G. A., and Torres-Valdés, S.: Picoeukaryote distribution in relation to nitrate uptake in the oceanic nitracline, Aquat. Microb. Ecol., 72, 195-213, https://doi.org/10.3354/ame01695, 2014.

Partensky, F., Blanchot, J., Lantoine, F., Neveux, J., and Marie, D.: Vertical structure of picophytoplankton at different trophic sites of the tropical northeastern Atlantic Ocean, Deep-Sea Res. Pt. I, 43, 1191-1213, https://doi.org/10.1016/0967-0637(96)00056-8, 1996.

Partensky, F., Blanchot, J., and Vaulot, D.: Differential distribution and ecology of Prochlorococcus and Synechococcus in oceanic waters : a review, Bulletin de l'Institut océanographique, 19, 457-475, available at: http://cat.inist.fr/ ?aModele $=$ afficheN\&cpsidt $=1218663$ (last access: 1 December 2017), 1999.

Pérez, V., Fernández, E., Marañón, E., Morán, X. A. G., and Zubkov, M. V.: Vertical distribution of phytoplankton biomass, production and growth in the Atlantic subtropical gyres, Deep-Sea Res. Pt. I, 53, 1616-1634, https://doi.org/10.1016/j.dsr.2006.07.008, 2006.

Pernthaler, J.: Predation on prokaryotes in the water column and its ecological implications, Nat. Rev. Microbiol., 3, 537-546, https://doi.org/10.1038/nrmicro1180, 2005.

R Core Team: R Development Core Team, available at: http://www. R-project.org (last access: 7 May 2018), 2016.

Ras, J., Claustre, H., and Uitz, J.: Spatial variability of phytoplankton pigment distributions in the Subtropical South Pacific Ocean: comparison between in situ and predicted data, Biogeosciences, 5, 353-369, https://doi.org/10.5194/bg-5-353-2008, 2008.

Rii, Y., Karl, D., and Church, M.: Temporal and vertical variability in picophytoplankton primary productivity in the North Pacific Subtropical Gyre, Mar. Ecol.-Prog. Ser., 562, 1-18, https://doi.org/10.3354/meps11954, 2016a.

Rii, Y. M., Duhamel, S., Bidigare, R. R., Karl, D. M., Repeta, D. J., and Church, M. J.: Diversity and productivity of photo- synthetic picoeukaryotes in biogeochemically distinct regions of the South East Pacific Ocean, Limnol. Oceanogr., 61, 806-824, https://doi.org/10.1002//no.10255, 2016 b.

Sarmiento, J. L., Slater, R., Barber, R., Bopp, L., Doney, S. C., Hirst, A. C., Kleypas, J., Matear, R., Mikolajewicz, U., Monfray, P., Soldatov, V., Spall, S. A., and Stouffer, R.: Response of ocean ecosystems to climate warming, Global Biogeochem. Cy., 18, GB3003, https://doi.org/10.1029/2003GB002134, 2004.

Schlitzer, R.: Ocean Data View, available at: http://odv.awi.de, last access: 1 December 2017.

Sherr, E. B., Sherr, B. F., and Wheeler, P. A.: Distribution of coccoid cyanobacteria and small eukaryotic phytoplankton in the upwelling ecosystem off the Oregon coast during 2001 and 2002, Deep-Sea Res. Pt. II, 52, 317-330, https://doi.org/10.1016/j.dsr2.2004.09.020, 2005.

Sieger, R., Grobe, H., Diepenbroek, M., Schindler, U., and Schlitzer, R.: International Collection of JGOFS (Joint Global Ocean Flux Study), Volume 2: Integrated Data Sets (1989-2003), https://doi.org/10.1594/PANGAEA.760907, 2005.

Stenegren, M., Caputo, A., Berg, C., Bonnet, S., and Foster, R. A.: Distribution and drivers of symbiotic and free-living diazotrophic cyanobacteria in the western tropical South Pacific, Biogeosciences, 15, 1559-1578, https://doi.org/10.5194/bg-151559-2018, 2018.

Tenório, M., Dupouy, C., Rodier, M., and Neveux, J.: Trichodesmium and other planktonic cyanobacteria in New Caledonian waters (SW tropical Pacific) during an El Niño episode, Aquat. Microb. Ecol., 81, 219-241, https://doi.org/10.3354/ame01873, 2018.

Van Wambeke, F., Catala, P., Pujo-Pay, M., and Lebaron, P.: Vertical and longitudinal gradients in HNA-LNA cell abundances and cytometric characteristics in the Mediterranean Sea, Biogeosciences, 8, 1853-1863, https://doi.org/10.5194/bg-8-18532011, 2011.

Van Wambeke, F., Gimenez, A., Duhamel, S., Dupouy, C., Lefevre, D., Pujo-Pay, M., and Moutin, T.: Dynamics and controls of heterotrophic prokaryotic production in the western tropical South Pacific Ocean: links with diazotrophic and photosynthetic activity, Biogeosciences, 15, 2669-2689, https://doi.org/10.5194/bg15-2669-2018, 2018.

Vaqué, D., Casamayor, E. O., and Gasol, J. M.: Dynamics of whole community bacterial production and grazing losses in seawater incubations as related to the changes in the proportions of bacteria with different DNA content, Aquat. Microb. Ecol., 25, 163177, https://doi.org/10.3354/ame025163, 2001.

Vazquez-Dominguez, E., Peters, F., Gasol, J. M., and Vaqué, D.: Measuring the grazing losses of picoplankton: Methodological improvements in the use of fluorescently labeled tracers combined with flow cytometry, Aquat. Microb. Ecol., 20, 119-128, https://doi.org/10.3354/ame020119, 1999.

Veldhuis, M. J. W. and Kraay, G. W.: Application of flow cytometry in marine phytoplankton research: current applications and future perspectives, Sci. Mar., 64, 121-134, https://doi.org/10.3989/scimar.2000.64n2121, 2000.

Venter, C. J., Remington, K., Heidelberg, J. F., Halpern, A., Rusch, D., Eisen, J. A., Wu, D., Paulsen, I., Nelson, K. E., Nelson, W., Fouts, D. E., Levy, S., Knap, A. H., Lomas, M. W., Nealson, K., White, O., Paterson, J., Hoffman, J., Parsons, R., Baden-Tillson, H., Pfannkoch, C., Rogers, Y.-H., and Smith, H.: Environmental 
Genome Shotgun Sequencing of the Sargasso Sea, Science, 304, 66-74, https://doi.org/10.1126/science.1093857, 2004.

Vidussi, F., Claustre, H., Manca, B. B., Luchetta, A., and Marty, J. C.: Phytoplankton pigment distribution in relation to upperthermocline circulation in the eastern Mediterranean Sea during summer, J. Geophys. Res., 106, 939-956, https://doi.org/10.1029/1999JC000308, 2001.

Wickham, H.: ggplot2: Elegant Graphics for Data Analysis, Springer-Verlag, New York, 2009.

Wright, S. W. and Jeffrey, S. W.: Pigment markers for phytoplankton production, Handbook of Environmental Chemistry, Volume 2: Reactions and Processes, 2 N, 71-104, https://doi.org/10.1007/698_2_003, 2006.
Zubkov, M. V. and Tarran, G. A.: High bacterivory by the smallest phytoplankton in the North Atlantic Ocean, Nature, 455, 224 226, https://doi.org/10.1038/nature07236, 2008.

Zubkov, M. V., Sleigh, M. A., Burkill, P. H., and Leakey, R. J. G.: Picoplankton community structure on the Atlantic Meridional Transect: A comparison between seasons, Prog. Oceanogr., 45, 369-386, https://doi.org/10.1016/S0079-6611(00)00008-2, 2000.

Zubkov, M. V., Burkill, P. H., and Topping, J. N.: Flow cytometric enumeration of DNA-stained oceanic planktonic protists, J Plankton Res., 29, 79-86, https://doi.org/10.1093/plankt/fbl059, 2007. 